\title{
RACIAL JUSTICE IN THE AGE OF THE GLOBAL ECONOMY: COMMUNITY EMPOWERMENT AND GLOBAL STRATEGY
}

\author{
ANTHONY D. TAIBI†
}

When a struggle can be resolved legally, it is certainly not dangerous; it becomes so precisely when the legal equilibrium is recognised to be impossible. (Which does not mean that by abolishing the barometer one can abolish bad weather.)

Antonio Gramsci ${ }^{1}$

\section{INTRODUCTION: THE GLOBAL ECONOMY AND RACIAL JUSTICE}

We are in the midst of radical changes in the structure of the economy and social life, changes that require us to rethink the old progressive paradigms. The globalization of finance and production, new technologies in communications and information, new methods in the organization of work, and the decline of locationspecific notions of community are producing vast changes in society that may well redound to the detriment of most non-elite

$\dagger$ Kutak Rock, Atlanta, Georgia. I want to salute the partners of Kutak Rock for their deep commitment to scholarly inquiry, public service, and the ideals of the legal profession, and to thank them for their indulgent support of my nonbillable endeavors. A version of this Article was originally presented at a University of Illinois Unit for Criticism and Interpretive Theory Colloquium. Responses to that presentation were made by Kal Alston and Carol Stabile; their insights and criticisms were invaluable. I also thank Larry Grossberg and Cary Nelson for their comments and assistance. A later version of this Article was presented as the Duke Law Journal Annual Lecture in November 1994; Jerome Culp responded at that forum, and I thank my former teacher for his participation and helpful comments. Helpful encouragement, comments and criticisms of this work were made by Michael Brun, Steve Bainbridge, Eric Freyfogle, Tom Rowe, Peter Alexander, Gloria Kay Miller, Joseph Capizzi, Mary Devlin, Stephen Feldman, Gary Peller, Mark Tushnet, Eugene D. Genovese, Anthony Cook, Stanley Fish, Deborah A. Ramirez, Rob Michaels, Travis Jordan, and Wythe Holt. This Article could not have been completed without the many intellectual contributions, encouragement, editing, sagacious scholarly advice, and moral support of Hester Lee Furey.

This Article is dedicated to my mother, Elaine Taibi, and my aunt and uncle, Doris and Richard Naiman, who worked for racial justice in the South a half-century ago, for their example, faith, inspiration, and support.

1. ANTON1O GRAMSCI, SElections fROM the Prison Notebooks 256-57 (Quintin Hoare \& Geoffrey N. Smith eds. \& trans., Int'l Publishers 1971) (1933). 
people, and particularly people of color, both in America and in the world. We are at a watershed, a moment of contradiction in which for some African-Americans opportunities have never been greater, and yet for others life is increasingly hopeless; a moment when, although every group seeks to frame its own troubles with the evocative and inspiring narratives and paradigms of the civil rights movement of a generation ago, civil rights models seem unequal to the task of resolving high racial tensions. Indeed, the language of civil rights that seemed so transformative and redemptive a generation ago is now often deployed for conservative purposes. At the same time, many "progressives" seem little concerned with the encroachments of the global economy upon the lives, cultures, and communities of non-elite people. Identity politics and multiculturalism have little to say about these vast changes in social relations.

All economic, social, and cultural relations, beliefs, and institutions exist in dialectical relationship with each other and exist in their historical context. Both the systems and forms of oppression and the strategies and institutions for fighting oppression exist in a context. The very definition of the term "racism" depends on the social and economic relations of the time. Racism and ideas about discrimination can be understood only within a particular historical context. Social and economic relations more generally must be understood as the processes and outcome of the dynamic interaction among the realms of individual subjective choice, state legal and regulatory structures, and social and cultural arrangements and assumptions. Both the meaning of racism and its material nanifestations depend on this dynamic. ${ }^{2}$ All choices and decisionmaking

2. This understanding of social relations emerges from the field of economic sociology, which is similarly concerned with this complex dynamic. It should be noted that throughout this Article, I distinguish sharply between economics as a field of study and set of methodologies on the one hand and neoclassical economic ideology on the other. In arguing that the ideology of neoclassical economic thought indirectly legitimates existing social and institutional economic arrangements, $I$ do not mean to deny that economic thought has also been a vehicle of profoundly important advances in human knowledge, nor do I mean to suggest that we may reject real empirical discoveries if they cut against our political preferences. The problem is not so much the factors that economic analysis includes, but rather what economic models exclude and how the importance of the excluded factors is thereby minimized.

Briefly, neoclassical economic ideology assumes that the economy is an analytically separate realm of society that can be understood in terms of its own internal dynamics. Although some economists include politics and culture as factors that influence economic behavior, these factors are more typically bracketed or minimized in models that focus on 
are necessarily rooted in a context of cultural norms and assumptions, and thus it is absurd to suggest that difference ought not to make a difference. ${ }^{3}$ The question is what difference should it make. But until very recently, our ideas about social progress have operated on the principle that difference should not make a difference. It is very difficult for us to even conceive of self-consciously racially or regionally located identifications without automatically assigning to them an ultimately antisocial character. As Gary Peller notes,

[T] he story of the struggle against racism ... follows the basic script of liberal progress more generally. Race consciousness is associated with status-based social coercion, where individuals are treated in a particular way because of the arbitrary fact of membership in a social group they did not choose. The transcendence of race consciousness represents a social movement toward the freedom of the individual to choose group identification.... Freedom from racial discrimination is but one instance of the historical move from status to contract, from caste to individual

purely economic factors. This Article assumes that economic transactions need to be understood as continually shaped and influenced by social, political, and cultural factors, and that the microeconomic decisions that people make can be fully understood only in their specific cultural, social, and political context. Moreover, by its insistence that the economy is analytically distinct from the rest of society, neoclassical ideology makes it seem "natural" to see government action and even changes in the existing rules that govern private parties as "external" interference with a market economy. Following the path of the Legal Realists, this Article assumes that the idea of "the market" necessarily includes a regime of legal rights and entitlements and therefore cannot be understood as distinct from its regulation. See Richard T. ELY, PROPERTY AND CONTRACT IN THEIR Relations to the Distribution OF WEALTH 51-66 (1914); ROBERT HALE, Freedom Through LAW 11-12 (1952); Oliver Wendell Holmes, Privilege, Malice and Intent, 8 HARV. L. Rev. 1, 3-4 (1894); see also Duncan Kennedy, The Role of Law in Economic Thonght: Essays on the Fetishism of Commodities, 34 AM. U. L. REV. 939, 964-65 (1985) (noting that the "free market system" in the United States is located within a late-19thcentury private law regime). Thus, a more accurate study of economics involves analysis on at least three distinct levels: microeconomic choices; state actions that structure an economy both through background ground rules like contract and property law and through more direct regulation; and social and cultural arrangements and assumptions. The efficiency of any particular economic arrangement depends on how the three levels fit together. See Fred Block, POSTINDUSTRIAL PossibILITIES: A CRITIQUe OF ECONOMIC DISCOURSE 21-29, 41-42 (1990). Thus, it can never be declared a priori that a particular organizational, institutional, or governmental regime is "efficient." The relative efficiency of different ways of doing or regulating business is always an empirical question. A preference for laissez-faire arrangements based on the unexamined claim that they are more efficient is what I mean by neoclassical ideology.

3. See Stuart Hall, Culture, Community, Nation, 7 Cultural Stud. 349, 361-62 (1993). 
liberty. Individualism and universalism are thereby linked together. ${ }^{4}$

Within the last twenty years, proponents of affirmative action and more recently of a movement known as "multiculturalism" have argued persuasively that supposedly neutral, universal norms are in fact quite racially and culturally specific. Yet ultimately both of these paradigms have been formed and exist within a framework of universalist assumptions, so what little reform they can accomplish runs counter to their ultimate view of the good. As Christopher Lasch observed of the new social movements, "[T]heir only coherent demand aims at inclusion in the dominant structures rather than at a revolutionary transformation of social relations." In other words, civil rights ideologies, rather than constituting a critique of liberal social relations and institutions, are instead an expression of them. Further, the United States today has a very different economic system and social, legal, and cultural relations than it did at the time of the civil rights movement. Thus, the very meaning of racial oppression today is different from what it was a generation ago, and the strategies for fighting it, however liberatory in their moment, must change accordingly.

This Article critiques the assumptions of those who believe that the strategies appropriate for fighting racial subordination in the past have a timeless value. I argue that, quite to the contrary, the liberal discourses that served the civil rights movement so well have run up against the limits that were there all along precisely because these discourses belonged to a particular historical moment. To make this argument, my work engages the emerging school of Critical Race Theory (CRT), ${ }^{6}$ in particular the work of

4. Gary Peller, Race Consciousness, 1990 DUKE L.J. 758, 774 (citations omitted). Civil rights ideology comprehends the issue of racial domination by viewing race relations through stock images about the nature of progress in liberal society and through the prism of a qualitative difference between liberal enlightenment and feudal hierarchy. The struggle against racism thus appears natural and inevitable, as simply another part of the teleological progression toward the liberation of social life.

Id. at 774-75.

5. Christopher Lasch, The Revolt of the Elites: Have They Cancelled Their Allegiance to America?, HARPER's, Nov. 1994, at 39, 40.

6. My understanding of the limitations of existing civil rights paradigms has been profoundly shaped by ongoing discussions in the emerging school of Critical Race Theory. Numerous conversations with and articles by my colleagues in CRT influenced this Article. These colleagues include Paulette Caldwell, John O. Calomore, Anthony E. Cook, Kimberle W. Crenshaw, Jerome M. Culp, Jr., Richard Delgado, Linda Greene, Angela P. 
Professors Kim Crenshaw and Cheryl Harris. My concern is that in relying primarily on the conceptual apparatus of "equal opportunity" and "disparate impact," we have been trying to solve complex and changing problems with inadequate, outmoded tools. In an era in which the oppression of Black people was carried out by local, parochial institutions for the benefit of local, parochial elites, a struggle based on the ideology of color-blind, universal, liberal individualism was indeed liberatory. Today, however, the economic, cultural, and political structure has changed to the extent that the ideology of universal liberal individualism is central to the colonization of non-elite communities worldwide. Although vicious, old-fashioned, in-your-face racism continues to exact a terrible price on people of color, ${ }^{7}$ racial subordination now more typically manifests itself in far more subtle ways, and our ways of attacking it need to change accordingly. The National Urban League, for example, has concluded that in recent years "more blacks have lost jobs through industrial decline than through job discrimination." ${ }^{\prime \prime}$ I believe that strategies for fighting racial inequality that do not take into account the rapid changes being effected in the nature of patterus of urban development, the U.S. economy, and its supporting institutions cannot respond effectively to the eco-

Harris, Cheryl I. Harris, Alex M. Johnson, Jr., Charles R. Lawrence III, Mari J. Matsuda, Kendall Thomas, and Gerald Torres. For a sampling of CRT scholarship, see Symposium, Race Conscionsness and Legal Scholarship, 1992 U. ILL. L. REV. 945. For a bibliography of CRT articles, see Richard Delgado \& Jean Stefancic, Critical Race Theory: An Annotated Bibliography, 79 VA. L. REV. 461 (1993).

7. Sec Mari J. Matsuda et al., Words that Wound: Critical Race TheoRY, AsSaultive SPEech AND tHe First AMENDMENT 20-26 (1993); PATRICia J. WilLIAMS, THE ALCHEMY OF RACE AND RIGHTS (1991); Charles R. Lawrence III, If He Hollers Let Him Go: Regulating Racist Speech on Campus, 1990 DUKE L.J. 431; Mari J. Matsuda, Public Response to Racist Speech: Considering the Victim's Story, 87 MiCH. L. ReV. 2320 (1989); see also GORDON W. AllPORT, THE NATURE OF PREJUdice 142-61 (1954); HARRY H.L. KITANO, RACE Relations 105 (1974) (arguing that "internationalization and repression may have dysfunctional effects upon the individual"); Martin K. Denis, Race Harassment Discrimination: A Problem That Won't Go Away?, 10 EMPLOYeE REL. L.J. 415, 432-35 (1984). The courts have recognized that racist treatment and harassment can cause severe emotional distress and stress-induced physical problems. See, e.g., Wade v. Orange County Sheriff's Office, 844 F.2d 951, 955 (2d Cir. 1988), superseded by Civil Rights Act of 1991, Pub. L. No. 102-166, 105 Stat. 1071 (codified in scattered scetions of 42 U.S.C.); Shepherd v. American Broadcasting Cos., 862 F. Supp. 486, 494 (D.D.C. 1994) (holding that although "[u]gly and inexcusable sexist and racist jokes and insults" would not support claims of post-traumatic stress disorder, such acts would support a verdict for intentional infliction of severe emotional distress); Agarwal v. Johnson, 160 Cal. Rptr. 141, 154 (Cal. 1979).

8. National Urban league, The State of Black America 1988, at 155. 
nomic and social dislocations of lower-middle-class and poor African-Americans. ${ }^{9}$

Professor Crenshaw, quite correctly I think, chastises those on the Left who would effectively "collapse issues of race into issues of class." ${ }^{" 10}$ However, a purely racial account fails to see that racism can mean many things, manifest itself in varying ways, with divergent material effects, depending on the institutional setting and structural conditions in which it takes place. ${ }^{11}$ What we need is a mode of analysis that will allow us to understand and critique racial and economic relations simultaneously. ${ }^{12}$ To that end, first,

9. See JoINT CENTER for POlTtical Studies, A POLICY Framework for RACIAL JUSTICE 2, 4-8 (1983). William Julius Wilson writes:

[L]iberal programs such as affirmative action ... are not really designed to deal with barriers to desirable jobs that are the result of the use of increasing automation, the relocation of industries, the segmentation of the labor market, and the shift from goods-producing to service-producing industries. These are the problems to which the black poor, other minority poor, and the white poor are especially vulnerable. ...

$[T]$ he sole concentration on policy programs dealing with racial bias makes it difficult for blacks to recognize how their fortune is inextricably connected with the structure and functioning of the modern American economy. Indeed, in this century economic expansion has greatly benefited racial minorities. However, the important question for poor blacks in the last quarter of the twentieth century is not simply economic growth but the nature of that growth. ... [T] he growth of corporate industries has been accompanied by an expansion in industrial technology and a consequent increase in unemployment for untrained workers.

William Julius Wilson, The Declining Significance of Race 179 (2d ed. 1980) (citations omitted).

10. Kimberle W. Crenshaw, Race, Reform, and Retrenchment: Transformation and Legitimation in Antidiscrimination Law, 101 HARV. L. REV. 1331, 1364 (1988).

11. The relationship between oppression based on class and that based on identity has not been addressed satisfactorily. We need to go much further than currently fashionable notions of "intersectionality," which imply essentially analytically separate systems of oppression (e.g., race, gender, class, sexual orientation, or ability) that at various points "intersect" with each other. A more satisfactory analysis begins with the recognition that each of these systems is interactive and dynamic, constantly shaping, defining, and being shaped and defined by the other systems. To coin a new term, perhaps we ought to speak of the "interactivity" of various systems of oppression. The problem for progressive theorists on both sides of this divide is to acknowledge simultaneously that all significant aspects of social relations exist in a dialectical relationship with all others, and to accept the impossibility of a unified field theory of oppression. Thus, for example, although racism is not just a subset or variation of economic relations, the meaning of racism cannot be comprehended separate and apart from the context of the economic relations in which it occurs.

12. The need for such analysis is exemplified by the debates over group mortality differentials. The U.S. government collects statistics about mortality rates and causes of death by race, gender, and region, but not by economic class. The overwhelming majority of developed countries do collect mortality statistics by class, and there is considerable debate in the western world about growing class mortality differentials. Most Western 
I want to examine the implications of our civil rights discourses, noting how the political moments of their origin and successful deployment differ from the racial problems of our time. Next, to demonstrate why I think the old models are no longer very useful for fighting racism or for bettering the lives of Black people, I will play out some of the assumptions that underlie them in the arena of credit discrimination. To illustrate why multiculturalism's conflict-free, United Colors of Benetton models are less than effective in addressing the injury that global economic changes are already visiting upon many African-Americans and on lower-middle-class people generally, I discuss ways that multiculturalism indirectly and directly supports the power of global elites. Finally, I consider some of the moral shortfalls of increasing globalism and the ethos of universalism that has underwritten that development, offering in conclusion some tentative proposals for ways to strengthen the bargaining power of local communities. It is the ambition of this Article to explain in the context of global economic changes why it is time for progressives and non-elites from all races and cultures to both shift their allegiance to local centers of power and authority and at the same time engage in strategic cooperation with other localities so as to create structures that will protect local interests at the regional, national, and international levels.

\section{Contextualizing Civil Rights}

One hundred years ago, in the infamous case of Plessy $v$. Ferguson, the Supreme Court held that a state law requiring railroads to segregate their passengers racially was not inconsistent with the constitutional requirement that the states not deprive their citizens of the equal protection of the laws. ${ }^{13}$ The doctrine

\footnotetext{
European countries have made the reduction of class mortality differentials a major objective of government policy, but the United States is absent from this international debate. Vicente Navarro, Class and Race: Life and Death Situations, 43 MONTHLY REv., Sept. 1991, at 1, 2. Indeed, the two major American medical journals, the New England Journal of Medicine and the Journal of the American Medical Association (JAMA), carry many articles on race and gender mortality differentials-JAMA has even published special issues on Blacks, Latinos, and women-but issues of class are entirely absent. In contrast, Lancet, the most prestigious medical journal in Europe, carries such articles. Id. at 6-7. Although I do not wish to minimize the importance of our debate and struggles over racial mortality differentials, this issue may be more completely understood and resolved within its larger structural economic context.
}

13. 163 U.S. 537, 548 (1896), overnuled by Brown v. Board of Educ., 347 U.S. 483 (1954). 
of "separate but equal" that Plessy articulated provided the rhetorical framework for the legal legitimacy of the generations of American apartheid that followed.

In dissent, Justice John Marshall Harlan savagely attacked the majority opinion and in language echoing the battle cry of abolitionists and radical Republicans ${ }^{14}$ thundered, "Our Constitution is color-blind, and neither knows nor tolerates classes among citizens." 15 Harlan's formulation defined the civil rights opposition to segregation, providing the rhetorical framework for the NAACP legal challenge to the Jim Crow system. ${ }^{16}$ Today, however, Justice Harlan's rhetoric of color-blindness is no longer a progressive discourse, but rather is employed by conservatives to demarcate the limits of racial reform in opposition to affirmative action. For example, Justice Scalia often evokes Justice Harlan's statement when writing to overturn affirmative action and minority set-aside programs. Concurring in City of Richmond v. J.A. Croson Co., Justice Scalia wrote, "[O]nly a social emergency rișing to the level of imminent danger to life and limb ... can justify an exception to the principle einbodied in the Fourteenth Anendment that '[o]ur Constitution is color-blind . . .."17 It would be a mistake, however, to assuine that today's conservative discourse is simply a badfaith distortion of a basically progressive civil rights vision; rather, our prevailing civil rights discourse contams within itself serious limitations to a hberatory movement for justice, limitations that have becoine more manifest in recent years. ${ }^{18}$

14. See Book Note, The Color-Blind Constitution?, 106 HARV. L. REV. 2027, 2027 (1993) (reviewing ANDREW KULL, THE COLOR-BLIND CONSTITUTION (1992)).

15. Plessy, 163 U.S. at 559 (Harlan, J., dissenting).

16. See Garrett Epps, Of Constitutional Seances and Color-Blind Ghosts, 72 N.C. L. REV. 401, 428-29 (1994).

17. 488 U.S. 469, 521 (1989) (Scalia, J., concurring) (quoting Plessy, 163 U.S. at 559 (Harlan, J., dissenting)).

18. Minimally, as Crenshaw has argued, civil rights legal doctrine, like all legal doctrine, is indeterminate as between its potentially narrow and broad interpretations and visions. Crenshaw, supra note 10 , at 1346 . The conservative side of color-blindness is the idea that but for past overt racial exclusion, America's social life and institutional culture are essentially culturally neutral, objective, and meritocratic. The assumption behind integration is that Black people should enter mainstream institutions, but that the institutions should stay the same. Following Black Nationalist critiques, Critical Race Theory apparently argues that being Black is more than skin-deep; that it is about being part of a historically situated cultural community whose values, outlook, and the like are not readily assimilable. Concomitantly, Critical Race Theory views mainstream institutions not as culturally neutral or even as simply culturally "American" meritocratic institutions, but 
My analysis is m no way intended to diminish the importance of previous civil rights struggles or disparage the accomplishments of those who struggled and sacrificed in the name of civil rights. I agree with Professor Crenshaw, a Critical Race Theory founder, when she argues, invoking the work of Italian social theorist Antonio Gramsci, that at the historical moment of the civil rights movement, a frontal assault against the structural forces that subordinated African-Americans would have resulted in defeat. More generally, she argues that social struggle in western societies must proceed along the hines of a Gramscian "War of Position,"19 in which oppressed people trigger a crisis of legitimacy within dominant institutions and turn the system's own logic against it. ${ }^{20}$ To the extent that a social movement finds itself constrained by this logic, it does not have the luxury to ask itself whether doing so further legitimates and entrenches the existing power structure.

rather as institutions deeply reflecting a highly particularistic elite White culture, a culture that in subtle and not-so-subtle ways excludes and marginalizes people of color. Thus, Critical Race theorists seem to reject the cultural compromise that says to the "talented tenth," "You can enter the corridors of power, just don't change anything, or rock the boat, and be thankful for the opportunity." Critical Race theorists presumably want to do more than just provide some color to institutions so that White liberals can feel good about themselves as their institutions remain essentially unchanged; Critical Race theorists want the opportunity to transform institutional life so that it reflects more of their own cultural values and expectations. The old guard's assumption that it can continue to set the agendas, expectations, and methodologies that everyone must follow in order to gain admission to the halls of power is in reality a demand for the maintenance of the racial and class status quo, for the right to play is limited without the ability to influence the rules of the game. See generally Jerome M. Culp, Jr., Water Buffalo and Diversity: Naming Names and Reclaiming the Racial Discourse, 26 CONN. L. REV. 209, 216 (1993) (contending that "majority scholars have engaged in a series of strategies to keep control of the discourse by silencing black voices and grandfathering the power of this entrenched majority").

19. Crenshaw, supra note 10, at 1386 (citing JOSEPH V. FEMIA, GRAMSCI's POLITical Thought: Hegemony, Consciousness, AND THE Revolutionary Process 51 (1981)) ("[T]he dominant ideology in modern capitalist societies is highly institutionalized and widely internalized. It follows that a concentration on frontal attack, on direct assault against the bourgeois state ('war of movement' or 'war of manoeuvre') can result only in disappointment and defeat."); see GRAMSCl, supra note 1, at 229-39.

20. Crenshaw, sipra note 10, at 1367. Crenshaw writes,

Such crisis occurs when powerless people force open and politicize a contradiction between the dominant ideology and their reality. The political consequences of maintaining the contradictions may sometimes force an adjustment-an attempt to close the gap or to make things appear fair. [The problem for social movements is that] because the adjustment is triggered by the political consequences of the contradiction, circumstances will be adjusted only to the extent necessary to close the apparent contradiction.

Id. at 1367-68. 
Rather, the only question must be, do the benefits of the available strategies outweigh their costs?

From the first, the ideologies of liberalism and capitalism were necessary to the Black struggle for justice in the United States. The manifest immorality of slavery was not enough to galvanize the political center to fight for its abolition. The Republican party-a coalition of abolitionists, yeoman White farmers, and nascent industrialists-resolved the structural contradiction of the incompatible social and economic systems that existed in the antebellum United States under a liberal capitalist ideology of "Free Soil" and "Free Labor." ${ }^{21}$ While radical abolitionist William Lloyd Garrison argued that the Constitution was "a covenant with death, and an agreement with hell," ${ }^{22}$ Frederick Douglass maintained that the issue was to extend the Constitution to Black people and fulfill the promise of the American ideology. ${ }^{23}$ Douglass's position reflected and reinforced the Republican party's institutional logic that was necessary to the successful prosecution of the war and abolition of slavery, but the limitations of that logic were quickly manifested after the war, as the promise of land redistribution was not kept and as moderate Republican leaders turned their attention towards business affairs. ${ }^{24}$ In Republican ideology, antislavery became but a subset of the human rights of individual property and "free" contract. ${ }^{25}$

21. See generally ERIC Foner, Free SOIL, Free LABor, Free MEN: THE IDEOLOGY OF tHE REPUBLICAN PARTY Before tHe CIVIL WAR (1970).

22. On the Fourth of July, 1854, Garrison burned a copy of the Fugitive Slave Law. "Then holding up the U.S. Constitution, he branded it as the source and parent of all the other atrocities,-'a covenant with death, and an agreement with hell,'-and consumed it to ashes on the spot, exclaiming, 'So perish all compromises with tyranny!'" DOCUMENTS OF UPHEAVAL: SElections FROM William LlOYD GARRISON'S THE LiBERATOR, 1831-1865, at 216 (Trnman Nelson ed., 1966).

23. In a speech given in 1852, Douglass stated, "[I]nterpreted as it ought to be interpreted, the Constitution is a GLORIOUS LIBERTY DOCUMENT. Read its preamble, consider its purposes. Is slavery among them? Is it at the gateway? or is it in the temple? It is neither." KULL, supra note 14, at 227 n.4 (quoting Douglass).

24. See C. Vann Woodward, The Strange Career of Jim Crow 67-82 (2d ed. 1966).

25. Compare The Civil Rights Cases, 109 U.S. 3, 25 (1883), superseded by 42 U.S.C. $\S 1985(3)$ (1994) (interpreting the Fourteenth Amendment narrowly with respect to the civil rights of individuals):

When a man has emerged from slavery, and by the aid of beneficent legislation has shaken off the inseparable concomitants of that state, there must be some stage in the progress of his elevation when he takes the rank of a mere citizen, and ceases to be the special favorite of the laws, and when his rights as a citizen, or a man, are to be protected in the ordinary modes by which other 
In this century, the Black struggle for justice has taken the form of "civil rights." By forcing open and politicizing the contradiction between the ideology of equality before the law and the reality of Black subordination under Jim Crow law, the civil rights movement succeeded in profoundly reshaping American society. The landmark Supreme Court civil rights cases, ${ }^{26}$ the Civil Rights Act of $1964,{ }^{27}$ and the Voting Rights Act of $1965^{28}$ demolished the formal barriers to the enfranchisement and economic participation of African-Americans. And because so much of the oppression of Black people hinged on these formal barriers, genuine and often profound changes followed their elimination.

We are now in the moment of disillusionment and confusion for the Black struggle for justice. ${ }^{29}$ A generation after the triumphs of the civil rights movement, much of Black America remains poor and without hope. Despite the enshrinement in the national ideology of the ideals of equal opportunity and civil rights for Black people, and despite some notable exceptions in certain segments of the Black population, many of these problems seem as intractable as ever. ${ }^{30}$ The manifest failure of civil rights law

men's rights are protected.

with Lochner v. New York, 198 U.S. 45, 53 (1905) (interpreting the Fourteenth Amendment broadly with respect to property rights, and invalidating state regulation limiting the working hours of bakers because "[t]he general right to make a contract in relation to his business is part of the liberty of the individual protected by the Fourteenth Amendment of the Federal Constitution").

26. See, e.g., the education cases, Brown v. Board of Education, 347 U.S. 483 (1954); Sweatt v. Painter, 339 U.S. 629 (1950); McLaurin v. Oklahoma State Regents, 339 U.S. 637 (1950); Sipuel v. Board of Regents of the Univ. of Okla., 332 U.S. 631 (1948), and the White-only political primary cases, Terry v. Adams, 345 U.S. 461 (1953); Smith v. Allwright, 321 U.S. 649 (1944); Nixon v. Herndon, 273 U.S. 536 (1927).

27. Pub. L. No. 88-352, 78 Stat. 241 (codified at 28 U.S.C. $\S 1447$ (1988) and in scattered sections of 42 U.S.C.).

28. Pub. L. No. $89-110,79$ Stat. 445 (codified at 42 U.S.C. $\S \S 1971,1973$ to 1973bb-1 (1988)).

29. As Crenshaw notes,

The passage of civil rights legislation nurtured the impression that the United States had moved decisively to end the oppression of Blacks. The fanfare surrounding the passage of these Acts, however, created an expectation that the legislation would not and could not fulfill. The law accommodated and obscured contradictions that led to conflict, countervision, and the current vacuousness of antidiscrimination law.

Crenshaw, supra note 10, at 1346.

30. See AlPhonso PINKNey, THE MYTH of Black Progress 87 (1984). A variety of statistical measures indicate the extent of these problems. For example, although the overall infant mortality rate fell from 1970 to 1991 , the Black infant mortality rate compared to that of White infants rose to over two to one (that is, White infant mortality 
and policy to live up to their promise has led many to reevaluate this strategy. ${ }^{31}$ Many White Critical Legal scholars, for example, have argued that the Black struggle for justice should abandon civil rights rhetoric and abstract procedural notions of justice, and

fell faster), and the rate of Black maternal deaths compared to figures for Whites remained at slightly over three to one in 1991. BUREAU OF THE CENSUS, STATISTICAL ABSTRACT OF THE UNITED STATES 91 (1994) (Table 120). While about one-fifth of all children in the United States lived below the poverty level in 1992, almost half of those were Black. Id. at 475 (Table 728). Although between 1960 and 1993 the percentage of Black people with high school diplomas more than tripled, and the percentage with Bachelor's degrees quadrupled, see id. at 157 (Table 232), almost $30 \%$ of the Black population over age 25 did not have a high school diploma as of 1993 and only $3.4 \%$ had advanced degrees. Id. at 158 (Table 234: Years of School Completed, by Selected Characteristics). Black high school graduates had a mean monthly income of about $\$ 400$ less than their White counterparts; Blacks with bachelor's degrees made about $\$ 550$ less. Id. at 158 (Table 235). In the aggregate, Black income went up between 1970 and 1988; however, per capita income and median family income for Blacks as compared to Whites actually declined slightly in those years. Overall, Black median family income remained in the range just below two-thirds of White median family income in this period. BUREAU OF THE CENSUS, MONEY INCOME AND POVERTY STATUS IN THE UNITED STATES: 1988, SERIES P-60, No. 166, at 36-37, 56 (1989) (Tables 7 and 16). The duration of unemployment tends to be longer for Black people than for Whites; specifically, Black men and women are less likely to be unemployed for a short period of time, but significantly more likely to suffer long-term unemployment (more than three months). 36 BUREAU OF LABOR STATISTICS, U.S. DEP'T OF LABOR, EMPLOYMENT AND EARNINGS ${ }^{\circ} 176$ (1989) (Table 15). For further statistical analysis of the disparities between Blacks and Whites, see National Urban league, The State of Black America 1994; Economic PolICY INSTITUTE, THE STATE OF WORKING AMERICA 1992-1994 (1994).

On the other hand, many conservatives argue that these problems have resulted not from the failure of civil rights, but rather from the unintended consequences of liberal social programs. See, e.g., Charles Murray, LOSING Ground: AMERICAN Social POLICY, 1950-1980 (1984).

31. As Crenshaw and others have argued, the ideological commitment to civil rights, antidiscrimination, and equal opportunity is radically indeterminate, containing within itself both a narrow vision of equality as process and an expansive vision of equality as result. The equality-as-result vision "interprets the objective of antidiscrimination law as the eradication of the substantive conditions of Black subordination" and sees the courts and other dominant institutions as appropriate vehicles for furthering this objective. Crenshaw, supra note 10 , at 1341 . The equality-as-process vision, which exists simultaneously with the substantive vision, sees the objective of antidiscrimination law as the prevention of further wrongdoing rather than the amelioration of present manifestations of past injustice. Id. at 1342. "'Wrongdoing, moreover, is seen primarily as isolated actions against individuals rather than as a societal policy against an entire group." Id. This vision also sees it as inappropriate for the courts and other dominant institutions to act as vehicles for the eradication of the present harms caused by our racist past, beyond "policing society to eliminate a ... set of proscribed discriminatory practices." Id. Although many conservatives argue that the notion of "civil rights" "really" refers to the restrictive, process-only view, in fact "there simply is no self-evident interpretation of civil rights inherent in the terms themselves"; rather, the interpretation argued for represents the politics and worldview of the interpreter. Id. at 1344. 
instead seek to delegitimate the authority of law and legal rights generally, and organize around substantive notions of justice and human need. Also invoking the work of Gramsci, such scholars argue that the hegemonic, legitimating power of liberal legal ideology prevents the realization of any significant liberatory possibility it may contain. ${ }^{32}$

Crenshaw and other Critical Race Theory scholars, on the other hand, argue that the White Critics have misread Gramsci. Crenshaw explains,

Articulating their formal demands through legal rights ideology, civil rights protestors exposed a series of contradictions-the most important being the promised privileges of American citizenship and the practice of absolute racial subordination. Rather than using the contradictions to suggest that American citizenship was itself illegitimate or false, civil rights protestors proceeded as if American citizenship were real, and demanded to exercise the "rights" that citizenship entailed. By seeking to restructure reality to reflect American mythology, Blacks relied upon and ultimately benefited from politically inspired efforts to resolve the contradictions by granting formal rights. ${ }^{33}$

Crenshaw agrees with the White Critics that "the need to maintain legitimacy that presents powerless groups with the opportunity to wrest concessions from the dominant order ... forecloses greater possibilities." ${ }^{34}$ She parts company with them, however, because

32. See id. at 1349-66 (citing and criticizing the work of various White Critics); see also Alan D. Freeman, Antidiscrimination Law: The View from 1989, in THE POLITICS OF Law: A Progressive Critique 121, 141-44 (David Kairys ed, rev. ed. 1990); Alan D. Freeman, Legitimizing Racial Discrimination Through Antidiscrimination Law: A Critical Review of Supreme Court Doctrine, 62 MINN. L. REv. 1049, 1111-13 (1978) (arguing that the Supreme Court revealed its brazen indifference to results by holding in Pasadena City Board of Educ. v. Spangler, 427 U.S. 424 (1976), that school district's renewed racial imbalance following one-year imposition of court-ordered remedial program was the result of "normal migration patterns"); Mark Tushnet, An Essay on Rights, 62 TEX. L. REV. 1363, 1394 (1984) (suggesting that satisfying people's need for food and shelter may be a more pressing concern than engaging in rights discourse).

33. Crenshaw, supra note 10, at 1368. Crenshaw further argues that within the context of America's racist reality,

engaging in reformist discourse is the only effective way [that Black people can] challenge the legitimacy of the social order. Perhaps the only situation in which powerless people may receive any favorable response is where there is a political or ideological need to restore an image of fairness that has somehow been Id. tarnished.

34. Id. 
she sees little to be gained for Black people through a strategy focused primarily on delegitimating dominant institutions. Thus the challenge for Black politics, as she sees it, is that it must engage in reformist practices while seeking to minimize the legitimation of dominant institutions that inevitably accompanies such reformist practice. ${ }^{35}$

Crenshaw's response appropriately rebukes those quarters of the Critical Left in which the trashing of dominant institutions, paradigms, and systems of authority and meaning sometimes seems to be an end in and of itself. Demonstrating the emptiness, contingency, indeterminacy, contradiction, incoherence, and reified nature of such liberal shibboleths as citizenship, constitutional rights, and legal authority may be great fun and even intellectually and emotionally liberating for a cosmopolitan elite, but it is a poor strategy for powerless people seeking material improvement in their condition. The apparent assumption of some on the Critical Left that once the false necessity and contingency of current arrangements is revealed, "the people," their ideological blinders removed, will remake the world in a better, more just way, is at best tactically naive. Dominant ideologies are simply too well entrenched and the human need for determinate systems of authority and meaning too great for a political strategy of wholesale deconstruction to have a viable liberatory trajectory. ${ }^{36}$

That being said, I nevertheless believe that Professor Crenshaw's Gramscian analysis takes a wrong turn regarding the present predicament of civil rights politics. Given that reformist politics is the only effective way to challenge the legitimacy of the social order, how can a movement avoid or minimize the "legitimating" effects of reformist politics? It ultimately carmot: a social movement that wrests concessions from the dominant order by politicizing contradictions within that system or by using the system's own internal logic against it will, at best, eventually find the internal contradictions resolved, the limits of the institutional logic reached, and, although conditions may be much improved, the possibilities

35. Id. at 1387.

36. Indeed, most of the recent successful attempts to undermine the legitimacy of dominant institutions-such as Congress, lawyers, the media, and even big business and Wall Street-have originated on the Right, not the Left. See, e.g., Richard I. Kirkland, Jr., Today's GOP: The Party's Over for Big Business, FonTUNE, Feb. 6, 1995, at 50; Big Business vs, the GOP?, WALL ST. J., Mar. 13, 1995, at A14. 
for structural transformation foreclosed by that selfsame institutional logic.

Professor Crenshaw's analysis obscures the fact that there is not a single dominant ideology and institutional logic, but rather a variety of contradictory, conflicting, and competing dominant ideologies and institutions, each with its own internal logic. ${ }^{37}$ This reality of competing hegemonic systems, each with its own institutions, elites, and ideology, is, for example, well illustrated by analyzing the United States during the time of slavery: that the dominance of liberal capitalism was not a foregone conclusion is demonstrated by the fact that it required one of the bloodiest wars in history up to that time to achieve its position. Thus, the question is not how a movement can avoid or minimize the "legitimating" effects of reformist politics; rather, the question is which of the available competing institutional frameworks offers the best possibilities as a vehicle for the liberatory transformation of society at this moment.

37. Many of my colleagues understand references to a "hegemonic" system to mean a system whose dominance is established and complete. I thank Stephen Feldman for pointing this out to me. However, my use of the phrase "competing hegemonic systems" is a considered one. In HEgEMONY AND SOCIALIST STRATEGY: TOWARDS A RADICAL DEMOCRATIC POLITICS (1985), Ernesto LaClau and Chantal Mouffe outline the history of the concept of "hegemony" in Marxist theory, analyzing in some detail the discursive processes by which "hegemony" evolved from a tactical concept, an attempt to explain "historical mutations" that seemed to contradict Marxist dogma, into an expanded concept that accounts for the entire social body and calls all of the old Marxist paradigms into question. One of the useful aspects of this concept is precisely that it places the mutability and indeterminacy of the social at the center of our theorizing (i.e., what was formerly thought of as a problem may now be seen as a resource). Id. at 143-45. Theorists in the field of Cultural Studies have emphasized this concept increasingly since the 1950s, as they have sought to uncover the processes by which individual consciousness, consumption patterns, and institutional practices interact and contribute to the manufacture of collective common sense and political consensus. Although some scholars in this field have a tendency to be overly optimistic about the transformative potential available in any given interaction of subjects, text, and social context, its major figures have repeatedly cautioned against complacent celebrations of consumer "resistance." As Stuart Hall has noted, the first fact of "hegemony" is struggle:

"Hegemony" implies: the struggle to contest and dis-organize an existing political formation; the taking of the "leading position"... over a number of different spheres of society at once-economy, civil society, intellectual and moral life, culture; the conduct of a wide and differentiated type of struggle; the winning of a strategic measure of popular consent; and .... the securing of a social authority sufficiently deep to conform society into a new historic project. It should never be mistaken for a finished or settled project. It is always contested, ... always "in process."

StUART HALl, THE HARD RoAd to RENEWAL: THATCHERISM AND THE CRISIS OF THE LEFT 7 (1988). 
Given this analytic frame, I believe that the liberatory potential of traditional civil rights approaches has been used up and that they have exhausted their power to explain, inspire, or guide politics and public policy. The contradictions in the dominant ideologies that traditional civil rights approaches so successfully politicized have been largely resolved. The victories achieved through liberal civil rights ideology - the right to vote, the end of legally enforced segregation, the legal enforceability of a right to be treated as an individual-have been substantial, but most of what can be comprehended by that institutional logic has been achieved. This is evident, I think, in the shift in intellectual and legal debates from questions about the desirability of civil rights, legal equality, and the eradication of racism to endless arguments over what the words even mean. Civil rights is a formal, procedural discourse well adapted to the needs of an era whose structures of oppression were largely crystallized in legal procedural forms. I am in no way suggesting that "the battle for civil rights was... won,"38 but rather that the insights, methodologies, and remedies of this discourse and strategy in the struggle for justice are not terribly useful in the struggles of today. To support these claims, let us consider for a moment some of the inherent theoretical difficulties with this discourse and then think through some of its implications with respect to two of its practical applications, equal credit opportunity and affirmative action.

Equality is the grand abstraction of the Left. Equal? Equal to what? According to what criteria? Equally degraded? The word "equality" does reflect some vague notions we have about fairness and justice, but the assumption that it stands for anything in particular is the height of reification, as eminently deconstructible as any of the Right's formulations. Equality does have some potentially determinate usages, but they are not particularly useful at.

38. Conservative economist and commentator Thomas Sowell argues that "[t]he battle for civil rights was fought and won-at great cost-many years ago." THOMAS SOWELL, CIVIL RIGHTS: RHETORIC OR REALITY? 109 (1984). Sowell's narrow vision of what civil rights "really" mean demonstrates his ideological commitments rather than some inherent meaning in civil rights discourse; however, the fact that his argument has almost become the conventional wisdom in conservative circles demonstrates that the "civil rights" tactic of the Black struggle for justice has run up against the limits of its usefulness. See Crenshaw, supra note 10, at 1336 (arguing that "the definitional tension in antidiscrimination law, which attempts to distinguish equality as process from equality as result, is more productively characterized as a conflict between the stated goals of antidiscrimination law") (citations omitted). 
this historical moment. ${ }^{39}$ When pressed, most people will say that what they mean by equality is equality of opportunity-but this too is a vague abstraction. Equality of opportunity can mean only the right to participate in a society not of one's own making whose rules necessarily unequally benefit and disadvantage its different members. My equal right to try out for the Chicago Bulls is unrelated to my ability to make the team. Your equal right to go into business is unrelated to your ability to make it succeed. Whether it is strength, cunning, economic resources, a silver tongue, beauty, the stomach for ass-kissing, artistic talent, or just plain luck, our abilities to make use of opportunities are necessarily unequally distributed. ${ }^{40}$ Our sense about the fairness of evaluative procedures and about the appropriateness of the social value granted to different pursuits is the stuff of political commitments and struggle, but a generalized commitment to equality is of little help in envisioning and implementing transformative social struggle.

At its heart, the equality paradigm assumes that human beings are all essentially rational, utility-maximizing individuals, and that societal institutions can and ought to operate rationally and neutrally, outside of cultural and particularistic systems of thought and meaning. In this view, culture and race are simply a veneer on top of a core, a foundation, of neutral rational being, and thus cultural identification is or at least ought to be of no more significant material consequence than a preference for chocolate or vanilla. This understanding of essential human nature and human institutions is implicit in the central civil rights legal concept of discrimination. In ordinary usage, the word "discrimination" means to make distinc-

39. We could mean precisely equal in the conditions of people's lives, as Kurt Vonnegut describes in his story "Harrison Bergeron": a nation in which the strong must wear weights, the beautiful must wear ugly masks, and the smart must wear noisemakers to distract them. Kurt Vonnegut, Jr., Harrison Bergeron, reprinted in THE WORLD TREASURY OF SCIENCE FICTION 3 (David G. Hartwell ed., 1989). If we don't mean this absurdity, then what do we mean by equality? See generally Peter Westen, The Empty Idea of Equality, 95 HARV. L. REV. 537 (1982) (arguing that equality is an empty principle and that the rhetoric of equality should be abandoned).

40. Moreover, as Crenshaw notes,

To demand "equality of opportunity" is to demand nothing specific because "equality of opportunity" has assimilated both the demand and the object against which the demand is made; it is to participate in an abstracted discourse which carries the moral force of the movement as well as the stability of the institutions and interests which the movement opposed.

Crenshaw, supra note 10, at 1347. 
tions. And indeed, in the Jim Crow era a variety of social decisions-about hiring and layoffs, school admissions, investment decisions, and the like-foreclosed Black participation purely on the basis of explicitly racial classification. The implicit assumption of the civil rights paradigm is that once such distorting racial criteria are removed, these decisions are then racially neutral. Thus, our common understanding of discrimination begins with several questionable premises: that there are, or even could be, neutral standards of merit; that those standards can be measured in an objective way; and that assimilation to the culture of the standard is a positive social goal on which everybody ought to agree.

A current concern of civil rights theory is to demonstrate that racial bias can exist in decisionmaking systems without the use of explicitly tacial criteria or without even the intention to discriminate. "Disparate impact" litigation attacks evaluative systems that, although utilizing rational, nonracial criteria, lead to racially unequal results. ${ }^{41}$ This more substantive theory, however, still assumes the possibility of neutral decisionmaking and further assumes that more racially "equal" results in the outcome of particu-

41. "Disparate impact" analysis, as developed in Title VII employment discrimination cases, e.g., Griggs v. Duke Power Co., 401 U.S. 424 (1971), holds that policies that discriminate in practice may violate Title VII even absent intent to discriminate. See also Wards Cove Packing Co. v. Atonio, 490 U.S. 642, 645-46 (1989) ("[A] facially neutral employment practice may be deemed violative of Title VII without evidence of the employer's subjective intent to discriminate that is required in a 'disparate-treatment' case."). To succeed on a disparate treatment theory, the plaintiff must prove that overt discrimination occurred, whereas in disparate impact cases, "the employer uses a neutral employment practice that causes a disparate-impact on the work force." Candace $S$. Kovacic-Fleischer, Proving Discrimination Afier Price Waterhouse and Wards Cove: Semantics as Substance, 39 AM. U. L. REV. 615, 619 (1990); see also Pamela L. Perry, Two Faces of Disparate Impact Discrimination, 59 FORDHAM L. REV. 523, 525-32 (1991) (identifying a "fault theory" and an "effects theory" in disparate impact analysis); Daniel Shaviro, Statistical-Probability Evidence and the Appearance of Justice, 103 HARV. L. REV. 530, 546 n.59 (1989) (outlining rationales for Title VII's statistical proof rule); Note, The Civil Rights Act of 1991 and Less Discriminatory Alternatives in Disparate Impact Litigation, 106 HaRv. L. REv. 1621, 1628-36 (1993) (describing the impact of the Civil Rights Act of 1991 on disparate impact analysis). In 1989, a conservative Supreme Court sought to scale back the effects standard for employment discrimination cases by dramatically reducing the burden of proof required to establish a business necessity defense. Wards Cove, 490 U.S. at 658-61. However, Congress responded by enacting the Civil Rights Act of 1991, Pub. L. No. 102-166, $\S 106,105$ Stat. 1071, 1074-75 (codified at 42 U.S.C. $\S 2000$ e-2 (1988 \& Supp. V 1993)). For a wide-ranging discussion of the use of disparate impact analysis in the fair lending context, see $A B A$ Conference Takes on Fair Lending; Justice, Agency Experts Field Qucstions, Banking Rep. (BNA) No. 63, at 263 (Aug. 22, 1994). 
lar social decisionmaking systems are necessarily in the interest of subordinated people.

My doubts about the analytic coherence and normative sufficiency of the equality principle have been confirmed by my research into credit discrimination and the Equal Credit Opportunity Act. $^{42}$ A great deal of evidence irrefutably demonstrates that Black people face a tougher time than White people in obtaining consumer credit, mortgage, and small-business financing. ${ }^{43} \mathrm{Al}-$ though traditional discrimination and disparate impact analyses do provide some measure of help in this area, they inadequately address this issue.

\section{DisCRIMINATION, SUBJECTIVITY, AND THE CREDIT MARKET}

Many Americans cannot conceive of having sufficient economic resources to seriously consider owning their own home or opening a business, and African-Americans are significantly overrepresented in this group. A commitment to the expansion of opportunity and to the self-determination of communities requires us to fight for the provision of credit to people currently marginalized by capital markets. As community reinvestment activists argue, credit is the lifeblood of a community, and its scarcity contributes to neighborhood decay, small-business failure, joblessness, and other social ills. ${ }^{44}$ However, the basic model of discrimination described earlier is counterproductive when deployed in this situation, because the terms in which the discrimination paradigm models the relationship under scrutiny do not work well in the lending

42. 15 U.S.C. §§ 1691-1691f (1988 \& Supp. IV 1992); see also 12 C.F.R. § 202 (1994) (promulgating Regulation B, which implements the Equal Credit Opportunity Act). My research into these issues is detailed in Anthony D. Taibi, Banking, Finance and Community Economic Empowerment: Structural Economic Theory, Procedural Civil Rights, and Substantive Racial Justice, 107 HARV. L. REV. 1463 (1994).

43. See Taibi, supra note 42 , at $1474-76$, and studies cited therein.

44. See Calvin Bradford \& Gale Cincotta, The Legacy, the Promise, and the Unfinished Agenda, in From REDLINING to REINVESTMENT: COMMUNITY RESPONSES To URBAN DISINVESTMENT 228, 229 (Gregory D. Squires ed., 1992) (arguing that "our existing small towns, inner cities, and minority communities have continued to decline" because of lack of private capital); Allen J. Fishbein, The Community Reinvestment Act After Fifteen Years: It Works, but Strengthened Federal Enforcement Is Needed, 20 FORDHAM URB. L.J. 293, 308 (1993) (advocating "tougher, more aggressive enforcement" of the Community Reinvestment Act, a law designed to prevent discriminatory lending practices). 
context and because a focus on racism as the primary source of the credit problems of Black people is economically naive. ${ }^{45} \mathrm{Un}$ derstanding this problem solely in term of discrimination obscures the relationship between the lack of investment in Black communities and the larger structural dynamic of disinvestment in lowermiddle-class commumities generally.

It is hard to say which aspect of the equality paradigm is less helpful as a means of remedying the credit problems of Black people-its focus on the possibility of objectivity in the evaluation process itself, or its problematic emphasis on elimmating loan officer discretion from that process. First, various assumptions must be discussed. The equality model assumes that "creditworthiness" can be objectively assessed. Banks are assumed to have an equal incentive to lend equally to all "creditwortly" customers. However, ratlier than reflecting actual ability and willingness to repay debts, particular credit qualifications are in fact only indicia associated witl, but not determining, successful collection of debts in a creditor's particular past-a past that typically included only White debtors. The notion of "equally qualified" borrowers overlooks the cultural specificity of the proxies by which creditworthiness is judged. For example, credit scoring systems have typically scored frequent home or job changes as significant negatives, indicating instability. For Black people facing serious housing discrimination and concomitant schooling problems for their children, however, such relocations may mean precisely the opposite: that the credit seeker is intent on bettering lis family's life and thus is an excellent credit risk. Indeed, the Federal Financial Institutions Examination Council has concluded that traditional employment stability requirements may be discriminatory. ${ }^{46}$

45. Indeed, the credit discrimination issue looks somewhat different when we analyze the racial differential in terms of acceptance rates, rather than denial rates, and correct for differences in application strength. Overwhelmingly, applicants with strong applications, regardless of race, are approved. A major study of mortgage lending discrimination by the Federal Reserve Bank of Boston found that although the Black-White differential is significant even after correcting for relative debt burden, loan-to-value ratio, weaker credit history, and other factors, comparable minority applicants would experience an acceptance rate of $83 \%$ compared to the actual White acceptance rate of $89 \%$. ALICIA H. MUNNELl ET AL., MORTGAge LENDING IN BOSTON: INTERPRETING HMDA DATA 2 (Federal Reserve Bank of Boston, Working Paper No. 92-7) (Oct. 1992) (discussing denial rates). Thus, even if all lending discrimination were eliminated, it would make only a modest impact on low-income Black neighborhoods.

46. FEderal FinanCial Institutions Examination Council, Home Mortgage 
Further, the inherent limits of the equality paradigm's normative vision are encountered rather quickly in the lending context. Relatively little non-consumer credit is granted based on the numbers alone. As John Maynard Keynes explained, "Our knowledge of the factors which will govern the yield of an investment some years hence is usually very slight and often negligible."47 Therefore, the decision to invest must be understood as a result of "animal spirits . . ., and not as the outcome of a weighted average of quantitative benefits multiplied by quantitative probabilities." ${ }^{248}$

LENDING AND EQUAL TREATMENT 3, 6 (1991). The Council also says that unrealistically high minimum loan amounts and property age and size standards may work unfairly against low-income and non-White communities. See also Joel G. Brenner \& Liz Spayd, Bankers Describe Roots of Bias; Cultural Prejudice and Traditional Home Loan Rules Hurt Blacks Series: Separate \& Unequal: Why Discrimination Persists, WASH. POST, June 8, 1993, at A1, A10; Mary Colby, Learning to Be Colorblind, MAG. BANK ADMIN., Jan. 1993, at 26 (discussing the impact of the Home Mortgage Disclosure Act). Several banks that have experimented with flexibility in credit scoring models have done so successfully. For example, NationsBank has broadened its definition of "credit history" to include rent and utility bill payments; this extension of the model has not increased defaults on loans at all. Id:; see also Richard Marsico, $A$ Guide to Enforcing the Community Reinvestment Act, 20 FORDHAM URB. L.J. 165, 216-17, 257-58 (listing examples of banks that have instituted flexible credit criteria); JAMES H. CARR \& ISAAC F. MEgBolugBe, FANNIE Mae Office of Housing Research, Proceedings: hMDA Data and MoRtgage MARKET DisCRIMINATION RESEARCH 2 (Dec. 9, 1992):

Regulators and secondary market representatives generally acknowledged that many conventional underwriting standards may have the unintended consequence of making it more difficult for minority and low-income applicants to obtain mortgages because of the applicants' unique credit and employment histories and the characteristics of the properties such applicants seek to purchase.

Mario Antoci, chairman and chief executive of the American Savings Bank in Stockton, California, argues that successful lending in minority communities requires that "[e]verything ... be looked at in a different way" with respect to credit standards indicia. Mario Antoci, Minority Lending Is Very Different Indeed, AM. BANKER, Dec. 2, 1994, at 11.

47. JOHN M. KEYNES, THE GENERAL THEORY OF EMPLOYMENT INTEREST AND MONEY 149 (1936).

48. Id. at 161. In Keynes' own words,

[A] large proportion of our positive activities depend on spontaneous optimism rather than on a mathematical expectation. ... Enterprise only pretends to itself to be mainly actuated by the statements in its own prospectus, however candid and sincere. Only a little more than an expedition to the South Pole, is it based on an exact calculation of the benefits to come. Thus if the animal spirits are dimmed and the spontaneous optimism falters, leaving us to depend on nothing but a mathematical expectation, enterprise will fade and die;--though fears of loss may have a basis no more reasonable than hopes of profit had before.

Id. at 161-62. Federal Reserve Board Chairman Alan Greenspan similarly argues that although the use of increasingly sophisticated credit scoring models aids banks in risk management, prudent business lending suggests that "the ultimate decision as to whether the credit is bankable should, after all, lie with the loan officer and his superiors, not a 
The decision to lend is based in part on a subjective determination that the loan-seeker's project is viable and that the loan-seeker himself is a person of good character who will truly extend himself to repay debts. ${ }^{49}$ Of course, lenders can look to objective criteria like collateral and credit history, and may consider how similar projects have fared in the past, but typically a decision to lend ultimately depends on how much a loan officer is willing to trust the judgment of the borrower and work with the borrower to make the numbers come out right. ${ }^{50}$ It is at these inevitable points of subjectivity that racism may enter the loan granting process.

In conventional usage, "racism" means allowing race, a supposedly irrelevant characteristic, to play a part in what ought to be a purely "rational" decision. Banker discretion necessarily creates an opportunity for racism (either intentional or unconscious) to enter the loan granting process. The liberal "equality" paradigm thus focuses on eliminating subjectivity from decisionmaking. ${ }^{51}$

machine." Greenspan Advocates Pricing Business Loans According to Risk, BANKING POL'Y REP., Oct. 17, 1994, at 12 (excerpt of speech by Greenspan).

49. Taibi, supra note 42, at 1480; see GREGORY D. SQUIRES, CAPITAL AND COMMUNITIES IN BLACK AND WHITE: THE INTERSECTION OF RACE, CLASS, AND UNEVEN DEVELOPMENT 72-74 (1994) (discussing factors that indirectly and directly lead to discrimination in lending against minorities).

50. See SQuiRES, supra note 49 , at $72-75$ ("While the information may be objective, evaluating the total package and making a final decision often entail subjective dimensions. ... Lenders are more likely to ... work with the applicant to secure a favorable outcome, in the case of nonminorities."); Regulators Looking at 200 Banks Targeted by Justice as Having Suspicious HMDA Data, Banking Rep. (BNA) No. 60, at 249, 250-51 (Mar. 1, 1993). Richard Syron, president of the Boston Federal Reserve Bank, states that the problem with lending disparities between White and minority loan applicants is that "few applicants fit a narrow definition of perfect. . . . Most applicants, white as well as minority, exceed some guideline for obligation or loan-to-value ratios or credit history, or require additional documentation. 'As a consequence . . . the mortgage decision is not a purely mechanical process.'" Id. (quoting Syron). Thus, Syron argues that discrimination may enter the loan decisionmaking process as a result of "loan officers being more willing to exercise discretion and put their own reputations at risk for people who look or talk like themselves than for others." Id. In addition, it is no doubt embarrassing to talk to people about their personal finances and to coach them into living a more creditworthy consumption lifestyle. Similarly, it is no doubt easier to take such paternalistic advice if it comes from someone with whom one has a natural rapport and feels comfortable. Given the reality of the racial comfort zones in this culture, it is difficult to see how the issue of differential coaching by loan officers could be solved other than by forbidding loan officers to coach anyone.

51. See Larry Riedman, Go the Extra Mile for Minority Borrowers, AM. BANKER, Dec. 7, 1992, at 4 ("The crucial questions ... are whether the shortcomings of the rejected minority applicants were worse than those of the successful non-minority ones, and 
However, this is a one-dimensional response to a complex and multifaceted problem, a response that is potentially disastrous for all parties concerned except big banks, the well-to-do, and already successful businesses. ${ }^{52}$ First, the elimination of banker discretion would hurt all "gray zone" loan applicants, Black and White alike, because the simplest way with the lowest transaction cost to eliminate racial disparity in rejection rates is to reject everyone who does not meet the quantifiable criteria. ${ }^{53}$ Second, the types of

whether the lender went to equal lengths to help all customers qualify."); Justice About Ready to Hit Another Bank with a Fair Lending Suit, Official Says, Banking Rep. (BNA) No. 63, at 563 (Oct. 17, 1994) ("What gets lenders in trouble is the amount of discretion given frontline employees.") (quoting Alexander C. Ross of Department of Justice Civil Rights Division). Federal Reserve Board Governor Lawrence Lindsey has decried the fact that the "current orientation of policy-making [is] driving us rapidly and inexorably toward the computer-based approach" in lending decisionmaking. Lindsey Questions Increasing Reliance on Data Systems to Combat Credit Bias, Banking Rep. (BNA) No. 63, at 279 (Aug. 29, 1994).

52. Federal Reserve Board Governor Lawrence Lindsey predicts that the increasing use of statistical models to determine loan eligibility will hurt minorities: "The intended beneficiaries of our drive to fairness may be in fact those who suffer the most, and as is so often the case, cleaning up the unintended consequences of the policy actions we take today are [sic] going to be the biggest challenge for tomorrow's decision makers." Gov. Lindsey Points to Difficulties with Statistics as Loan-Eligibility Tool, Banking Rep. (BNA) No. 63, at 280 (Aug. 29, 1994). Given that smaller local banks give better service to local small businesses than do big banks, restrictions on banker subjectivity may ultimately harm the very communities such regulation is designed to help. See Anthony D. Taibi, Race Consciousness, Communitarianism, and Banking Regulation, 1992 U. ILL. L. REv. 1103, 1109-12; Arthur E. Wilmarth, Jr., Too Big to Fail, Too Few to Serve? The Potential Risks of Nationwide Banks, 77 lowA L. REv. 957, 1039 (1992).

53. This "leveling downward" seems especially likely because, as most studies of lending discrimination show, it is already true that clearly qualified applicants, both White and non-White, are generally approved for credit, while all applicants that are clearly unqualified generally are denied credit. "The disparity occurs in the treatment accorded the large middle groups of applicants who might qualify for a loan but have some problems or weaknesses in their applications." See OCC Announces New Procedures and Testers Pilot to End Home Mortgage Discrimination, Banking Rep. (BNA) No. 60, at 651 (May 10, 1993); MUNNELL ET AL., supra note 45, at 2-3. Loan officers make extra efforts for only some of these applicants, but although this extra effort is apparently expended more often for White than for Black applicants, it is unclear that "racism" is the dominant motivation for the exercise of this discretion. Because bank regulators question an institution that has identical middle-group applications in which Whites are approved proportionately more often than Blacks, regardless of how many similarly situated Whites are also turned down, and because a loan officer cannot make "extra" efforts for all applicants, it seems likely that anti-"discrimination" policy will lead banks to remove officer discretion and reject more applications generally. Indeed, the removal of discretion is already the preferred method of achieving low-transaction-cost "equality" at big banks. For example, Wells Fargo Bank in San Francisco "processes its loan applications in central loan production centers where credit officers use uniform criteria, such as debt-toincome ratio, credit history, time on the job and collateral." Colby, supra note 46, at 27. 
jobs (loan officers) and institutions (small banks) that exist by making use of this discretion would be destroyed because they rely on the character loan and their intimate knowledge of the locale to hold their own against the market encroachments of large banks. As Federal Reserve Board Chairman Alan Greenspan has explained, people who personally know individuals in the local business community have an informational advantage over outsiders and thus can be the low-cost service providers to small local businesses. $^{54}$ Thus, although the subjective points in the lending process are fraught with danger for non-White loan applicants, they are nonetheless potentially more beneficial than the alternative: a streamlined institutional process that would not allow lenders to extend the benefit of a doubt. The subjective point in the lending process is paradoxically the site at which both the worst and the best lending practices transpire.

In general, we want lenders to take a chance on a project whose numbers may be less than perfect if their intuition is that it will nevertheless succeed. The resulting tension-between the requirement that lenders treat everyone alike and the desire for the economic and social benefits derived from trusting lenders' intuitive professional judgments and allowing them to treat people differently based on those judgments-appears when we place side by side two of President Clinton's banking initiatives: the fair lending initiative and the small-business credit crunch initiative.

Therefore, boasts a Wells Fargo spokesperson, credit officers approve and deny loans without ever meeting the applicants or even knowing their race. Id. at 27-28. Indeed, a recent Chicago Tribune editorial by David M. Messick, professor at Northwestern University's J.L. Kellogg Graduate School of Management and director of the Center for the Study of Ethical Issues in Business, argues that the problem of mortgage discrimination is not so much the rejection of otherwise-qualified Black applicants, but the approval of mortgage loans to "unqualified" White applicants. The clear implication of Professor Messick's argument is not that more Black people should receive financing, but that these "unqualified" White people should not. David M. Messick, Mortgage-Bias Complexities, CHI. TRIB., Mar. 1, 1994, at A19. The available data, however, do not indicate that such "unqualified" White applicants have higher than normal failure rates.

54. Clinton Plans Regulatory Changes to Ease Lending, Reduce Credit Crunch, Banking Rep. (BNA) No. 60, at 248, 249 (Mar. 1, 1993). More recently, recognizing that lending creates a relationship and that we need to learn more about the credit needs of "[t]he community of small businesses [that] comprises diverse enterprises, with very different financing needs, management skills, and economic prospects," the Federal Reserve has launched its second survey of small-business financing. John P. LaWare, Statements to the Congress, FED. RESERve BulL., Dec. 1994, at 1080, 1082. The first such survey, conducted in 1989, showed indisputably "that local commercial banks are the primary suppliers of most financial products used by established small firms." Id. at 1080. 
Understanding the credit problems of Black people in terms of "discrimination," the Clinton administration's "fair lending" initiatives seek to reduce the discretionary aspects of the lending process and to ensure that lenders are equally helpful, patient, and accommodating to applicants from different racial or ethnic groups. ${ }^{55}$ In contrast, a key component of the administration's small-business credit crunch relief plan was to restore discretionary powers to lenders, so that they could make more "character loans" based largely on their subjective judgments of reputation. ${ }^{56} \mathrm{Al}-$ though both of these initiatives are laudable, and not necessarily inconsistent, in practice they are in tension. In this society as it is currently constituted, as opposed to some liberal fantasy, White people do not know Black people, and therefore reputational lendimg by White institutions cannot help but be "discriminatory."

Unfortunately, the solution cannot be anything so simple as having financial institutions hire more members from the communities they serve so that the situation described above would work to the benefit of those now shut out of the process. ${ }^{57}$ To make a large, White-owned bank more responsive to the needs of its cus-

55. The administration's initiatives use both the regulatory process and the litigation process. See, e.g., Federal Bank Regulators Step Up Scrutiny of Overages by Loan Originators, Banking Rep. (BNA) No. 63, at 410 (Sept. 26, 1994); Justice, Chevy Chase Savings Settle Marketing Claims Under Civil Rights Laws, Banking Rep. (BNA) No. 63, at 290 (Aug. 29, 1994); Bank Regulators Send Letter to CEOs Listing Steps to Beef Up Fair Lending, Banking Rep. (BNA) No. 60, at 827 (June 7, 1993); OCC Announces New Procedures and Tester Pilot to End Home Mortgage Discrimination, supra note 53, at 651; Riedman, supra note 51, at 4.

56. See Interagency Policy Statement on Credit Availability, Fed. Banking L. Rep. (CCH) I 51, 1493 (Mar. 12, 1993); Acting Comptroller Steinbrink Fills in Some Gaps of Clinton Credit Crunch Plan, Banking Rep. (BNA) No. 60, at 367 (Mar. 22, 1993); Clinton Unveils Small Business Credit Crunch Relief Plan; Fetv Details Offered, Banking Rep. (BNA) No. 60, at 329 (Mar. 15, 1993); Clinton Plans Regulatory Changes to Ease Lending, Reduce Credit Crunch, supra note 54, at 248. The congressional response linked this issue to banker concern with regulatory burden more generally, and the legislation that emerged reflected that merging of liberal desires and industry viewpoint. Riegle Community Development and Regulatory Improvement Act of 1994 (Community Dev. Banking and Financial Institutions Act), Pub. L. No. 103-325, 108 Stat. 2160.

57. But see Bob Hall, Redlining Black Faces, S. Exposure, Spring 1989, at 26. Mario Antoci, chairman and chief executive of the American Savings Bank in Stockton, California advises that successful lending in minority communities requires bank executives to staff facilities in such communities "with personnel who can speak the language of the customer base." Antoci, supra note 46, at 11; cf. SQUIRES, supra note 49, at 73-74 ("The small number of minorities employed in lending institutions exacerbates these problems. . . . And even when [a] loan officer[] is nonwhite, applications brought in by that person are frequently scrutinized more carefully than others, often adversely affecting minority homeseekers."). 
tomers in a Black neighborhood by staffing that branch with African-Americans might well redound to the detriment of the careers of those Black loan officers. The best opportunities for career advancement and bonuses are unlikely to be found in lower-middleclass neighborhoods. If a bank located primarily in White communities were to restrict some Black employees to working in Black neighborhoods, serious Title VII employment discrimination violations would ensue.

In summary, as long as the main business of a bank is beyond a particular local community, it is difficult to imagine how members of that community could be treated "equally" by the institution. $^{58}$ Within the larger context of an economy and financial structure driven by highly mobile transnational capital and corporate interests, community-based economic development will always be a charitable afterthought, not an economic imperative. Simply hiring members of the discriminated-against minority group to

58. In response to the calls of grassroots activists for community-based financial institutions to promote economic development, Congress and the Clinton administration recently enacted the Community Development and Financial Institutions (CDFI) Act, which establishes the CDFI Investment Fund "to promote economic revitalization and community development through investment" in CDFIs. Riegle Community Development and Regulatory Improvement Act of 1994 (Community Dev. Banking and Financial Institutions Act), Pub. L. No. 103-325, § 102, 108 Stat. 2160, 2163. CDFIs have already had notable success, such as the non-gentrified development of Chicago's South Shore neighborhood, spurred in large measure by the country's most successful CDFI, the South Shore Bank. The continued growth of these institutions holds great promise for self-determined, community-based economic empowerment. Outgrowths of a transracial movement that transcends the liberal-conservative dichotomy, CDFIs are not entirely market-driven, nor are they charities or bureaucratic government programs. Rather, controlled by neighborhood leaders and rooted in local experiences, they are responsible local businesses dedicated to helping the local community, institutions, and people to help themselves. However, as might be expected in our current political climate, little public money is being placed in the CDFI Investment Fund, and half of the Fund will be devoted to commercial bank-sponsored programs and "partnerships" rather than true CDFIs. See Taibi, stupra note 42 , at 1520-36. Indeed, the major banking initiative of the Clinton administration and congressional Democrats last year was forging a bipartisan consensus for an interstate banking act. Riegle-Neal Interstate Banking and Branching Efficiency Act of 1994, Pub. L. No. 103-328, 108 Stat. 2338. The Act will effect changes in the structure of finance that will hurt low- and moderate-income communities, and disproportionately people of color, far more than CDFIs, anti-lending discrimination efforts, and Community Reinvestment Act regulatory changes will help, all the while making it seem as though this lack of investment were simply the result of some natural phenomenon and not the result of policy. A community empowerment approach to community development banking would attempt to structure the rules of the game "so that CDFIs and small banks could successfully compete, and would make that outcome appear automatic and natural." Taibi, supra note 42 , at 1536. 
serve as loan officers in their communities might ghettoize Black professionals and could run afoul of employment discrimination laws. In addition, such a solution would do nothing for the credit problems of low-income White people.

Even in the absence of a desire to treat Black people unfairly, rational evaluative systems often lead to racially disproportionate outcomes, because of the continuing economic, cultural, educational, and social effects of past overt racial subordination and exclusion, and because African-Americans do not have sufficient institutional resources of their own. Recognizing this reality (and the difficulty of proving a hidden desire to discriminate), the focus of civil rights shifted in the 1970s from equality of individual opportumity and the elimination of racial categories to outcome-oriented affirmative action and disparate impact theories. ${ }^{59}$ Like the equality paradigm that preceded it, affirmative action ideology has brought much beneficial material success to people of color and remains a viable tactic for the transformation of particular local situations; nevertheless, I argue that affirmative action likewise obscures as much as it illuminates and legitimates the very social relations we should be fighting against.

\section{Contextualizing Affirmative Action Consciousness AND THE TROPE OF "WHITE"}

The affirmative action principle, although more realistic than the equality principle, is even more contradictory in its prennises: it seeks to ameliorate directly inequalities produced through the usual course of business im institutional life without addressing how such institutions continually produce inequitable results. But manifest racial disparity is not merely an aberration of institutions that are otherwise fair, neutral, and serving the needs of all of the American people equally and unprobleinatically; rather, manifest racial disparity provides the most visible indicator of how institutions like banks, universities, and law firins are more generally illserving non-elite communities and the lower middle class. When removed from its moorings as a local tactic and raised to the level

59. Although community-based civil rights organizations had long demanded racebased economic redress-such as the demand that African-Americans be hired in proportion to their patronage-resembling contemporary affirmative action, before Brown lcgal representatives of major civil rights groups largely confined their aims to the achievement of formal legal equality. Epps, supra note 16, at 435-38. 
of central principle and strategy, the implicit message of affirmative action becomes this: that the current arrangements of the market and measurements of merit, the things that determine the rewards and privileges of society, are fair and legitimate but for racism; that Whites who fail are unworthy; that the degraded position of lower-class Whites is deserved. ${ }^{60}$

Like the equality paradigm, affirmative action assumes that we can meaningfully speak of rational evaluative systems free of the "distortions" of racism and cultural preferences. ${ }^{61}$ Critical Race theorist Cheryl Harris argues that a principled affirmative action would require "that individuals receive that share of the benefits they would have secured in the absence of racism." 62 However, because all decisionmaking is bound up with systems of cultural meaning, this requirement is a practical impossibility. Moreover, although Harris is correct in arguing that "[r]efusing to implement affirmative action as a remedy for racial subordination will not alleviate the class oppression of poor whites," does allow elite institutions cheaply to buy the perception that they are fair, fending off more general attacks on their legitimacy, as well as dividing along racial lines those with a common interest in fighting against the logic of those institutions. Harris argues that by unmasking the racial character of market values, affirmative action more generally destabilizes dominant institutions and evokes "counterhegemonic possibilities of another vision of rights and ... equality ... around which to mobilize resistance." ${ }^{.64}$ It is precisely my growing conviction that this is not and will not be so that has led me to engage in this critique. ${ }^{65}$

60. There are some indications that the White underclass is the fastest-growing underclass segment. If this trend continues, will it constitute a triumph for racial justice when degradation is equal? See Dennis Farney, Elite Theory: Have Liberals Ignored "Have-Less" Whites at Their Own Peril?, Wall ST. J., Dec. 14, 1994, at 1; Charles Murray, The Coning White Underclass, Wall ST. J., Oct. 29, 1993; at A14; David Whitman et al., The White Underclass, U.S. NEWS \& WORLD REP., Oct. 17, 1994 at 40; see also BUREAU OF THE CENSUS, supra note 30, at 475 (Table 728). The percentage of White children living below the poverty level has increased by one-third since 1970, compared to an increase of only one-eighth in the percentage of Black children living in poverty. Id.

61. See Cheryl I. Harris, Whiteness as Property, 106 HaRV. L. REV. 1707, 1784 (1993).

62. Id. at 1783 .

63. Id. at 1786 .

64. Id. at 1779 n.299.

65. As Professor Crenshaw has persuasively argued, racism is central to American 
Far from mobilizing general "counterhegemonic" resistance, affirmative action falsely constructs a coherent White identity that seemingly unites the culture of the corridors of power with that of all Caucasian ${ }^{66}$ peoples. Gary Peller argues, correctly I think, that "we will never get to a serious negotiation over the terms of our institutional ... spaces until we start to recognize that they are not culturally 'neutral' but are the embodiment of specific cultural understandings." ${ }^{\prime 67}$ I part company with Peller, however, in his argument that we ought to understand the particular culture of our dominant institutions as "White." The particular culture of our elite institutions, of corporate boardrooms, of elite law schools and law firms, of investment banks, of advertising agencies, and of the obligatory social gatherings of all these institutions is foreign, alienating, and hostile to almost everyone not born into it. Many of us were drawn to Leftist politics because it explained why we felt alienated from institutions that most folks in them found unproblematic. We could never accept institutional claims of rationality and fairness, because the imstitutions always seemed unfair and arbitrary to us. Some of our ranks who came in as outsiders sucked it up and learned to conform and even love it, some of us were thrown out, and some went crazy and dropped out. Some of us got fed up and quit. The rest of us live with an uncomfortable tension, neither wholly inside nor out, making the best of it, but

ideology, and although beliefs abont the absolute biological inferiority of Black people have been replaced in popular consciousness with beliefs of cultural inferiority (but see Richard J. HeRrnstein \& Charles Murray, The Bell CuRve (1994) (arguing that cognitive ability is substantially an inherited trait)), the absence of Black people from elite institutions-now by their failure to "make it" rather than through rules of exclusion-reinforces the sense that evaluative procedures are, in fact, meritocratic. Thus, exposing the racialized nature of evaluative systems, rather than leading to a transracial politics of systemic reform, leads to White backlash. Crenshaw, supra note 10, at 1370-76. It is unlikely that disappointed White applicants will turn their sense of failure into a general critique of evaluative systems, or even accept Harris's suggestion that their failure would be the meritocratic outcome but for racism. What we see everywhere instead is an exaggerated defense of the meritocratic nature of existing institutions but for affirmative action.

66. The American Heritage Dictionary defines Caucasian thus: "Of, relating to, or being a major human racial division traditionally distinguished by physical characteristics such as very light to brown skin pigmentation and straight to wavy or curly hair, and including peoples indigenous to Europe, northern Africa, western Asia, and India." AMERICAN HERITAGE DictionaRY 304 (3d ed. 1992).

67. Gary Peller, Notes Toward a Postmodern Nationalism, 1992 U. ILL. L. REV. 1095, 1098-99 (arguing that we must " 'crack open' the veil of naturalness that marks so much of institutional life.") 
living in a world of catch-up, while others seem to have a guidebook that we were denied. But calling the culture and methodologies of elite institutions "White" is worse than just the obfuscation that would result from, say, calling them "American": calling them "White" obscures their particular elite content, allows the elite to hide behind an overgeneralized "Whiteness," and makes more difficult a multiracial alliance in opposition to that culture. ${ }^{68}$

I want to make it clear that I accept the claim that racism often overwhelms other systems of oppression. However, I argue that success on the racial front requires that we link racial disadvantage into the larger structures of which it is now often a part. In the emerging global economic system, a corporate manager in New York will have more in common with her brothers and sisters in office towers in Tokyo, Jakarta, Munich, Seoul, Beijing, Singapore, Paris, Cairo, and Johannesburg than she will with the people of her own race across town. As a pedagogic matter, when I was a professor I found that the best way to get many White students to appreciate the racialized nature of meritocratic systems was to validate their own experiences of cultural disadvantage and alienation in elite institutions. Unlike White liberals, my White lower-middleclass students did not go home to flagellate themselves for their "White skin privilege," but they did, I think, go into the world with a better appreciation of the cultural barriers that people of color struggle against and with a genuine desire to see beyond the surface in claims of meritocratic evaluation. This seems to me a more enduring basis for a grassroots liberatory political agenda. Civil rights ideology, whether expressed as equal opportunity or affirmative action, or in newer figures of multiculturalism and diversity, is of limited value in understanding the larger structural conditions in which racial oppression today takes place.

68. In addition, although an artifact of a social movement that purports to celebrate difference, the trope of "White" serves to erase ethnic cultural identity and difference. It is indeed bizarre that the relatives of Holocaust victims, Jews and Gypsies, are lumped together with members of the Aryan "race," as are the English with Indians and Pakistanis, Bosnians with Serbs and Croats, Algerians with the French, Palestinians with Israelis, and Russians with Chechyns, Ukrainians, Georgians, Uzbecks, and so on. All are lumped together and accorded an officially classified status for treatment the same as each other but different from those whose ancestors hailed from outside of the areas of Europe, the Mediterranean, North Africa, the Middle East, India, Pakistan, and Southwestern Asia. It is as if the ideology of America as the "melting pot"--an ideology supposedly discredited and considered to be oppressive by liberal intellectuals-were resurrected for all of these heterogeneous peoples. 


\section{Multiculturalism AND POSTMODERn COLONIALisM}

Although, as I have argued, economic decisions are always cultural decisions, politics based primarily on a cultural foundation obscures this link. This is largely the case with "multiculturalism." To be sure, many of the insights of multiculturalism are absolutely indispensable to a politics of liberation and justice: shared social spaces like universities must respect and foster diverse cultural identities and systems of meaning. The equal protection of the laws and the mission of scholarly inquiry demand no less. But it is a hollow victory if we achieve multiculturalism in our shared social spaces while most people go home to dying communities.

Multiculturalism correctly exposes the false claims of universality in dominant institutions, which in fact represent the culture of dead White European males; however, it simply replaces that dead White European male culture with an equally particularistic elite liberal cosmopolitan culture that it then declares to be universal. Multiculturalism is highly selective in the attributes of diverse cultures that it selects for inclusion, and its evaluative criteria are highly particular. As a matter of taste and aesthetics I sliare most of its preferences, but conformity to the contemporary preferences of intellectuals hardly constitutes the transcendence of particularity and cultural bias. Moreover, multiculturalism, even more than its civil rights forebears, is almost entirely an internal critique, seeking to change the norms and evaluative systems of institutions from the inside, giving little thought to analysis of relations between institutions or to how institutional life more generally ought to be structured. ${ }^{69}$

The politics of multiculturalism, as it is currently constituted, helps reinforce the legitimacy of rule by global elites both indirectly and directly. Indirectly, we send a message and structure our thinking not only by what we choose to struggle over and talk about, but also by what we choose not to struggle over and talk about. The subtle message multiculturalism sends is that economics and the structure of markets and business decisionmaking ought to be of peripheral or at best secondary concern to those who care about human liberation, justice, and cultural integrity. Indeed, I have found that progressive, compassionate people who have the

69. Cf. Lasch, supra note 5 , at 40 (arguing that the new social movements have as "their only coherent demand" the inclusion in dominant social structures, rather than the "revolutionary transformation of social relations"). 
most interest in liberatory political ideas are among those least knowledgeable about or interested in economics and business affairs. To the extent that multiculturalism and the politics of representation dominate our struggle for racial justice, we neglect and marginalize what ought to be a central concern: the economic integrity of communities on which cultural integrity ultimately depends. To the extent that multiculturalists do engage economic issues, it is typically over particular ad hoc social programs, not structural economic reform. This programmatic approach makes economic justice a question of charity and does nothing to challenge the overall dynamics of the system. Far from being counterhegemonic, multiculturalism is in fact now the language of successful global business elites. ${ }^{70}$

I urge progressive people to take a look at the expanding business management literature on how to manage efficiently today's workforce and restructure corporations so that they will be successful in the emerging global marketplace. This literature looks amazingly similar to literature on multiculturahism that purports to have a progressive perspective. ${ }^{71}$ For example, a recent book, The

70. David Rieff, Multiculturalism's Silent Partner: It's the Newly Globalized Consumer Economy, Stupid, HARPER's, Aug. 1993, at 62, 69:

[C]apitalism is the bull in the china shop of human history. The market economy, now global in scale, is by its nature corrosive of all established hierarchies and certainties, up to and including-in a world now more than 50 percent nonwhite and in which the most promising markets lie in Asia-white racism and male domination. If any group has embraced the rallying cry "Hey, hey, ho, ho, Western culture's got to go," it is the world business elite.

A recent survey of Fortune 500 firms found that $72 \%$ now have formal "diversitymanagement" programs. Leon E. Wynter, Business \& Race, WALL ST. J., Dec. 21, 1994, at B1; see also Put on Your Helmets for the Culture War, FoRTuNE, Feb. 6, 1995, at 60 (noting that almost 100 major U.S. corporations have formally pledged "not to be influenced by 'sexual orientation' " in hiring, firing, or promoting, and discussing the many corporations, including some of the fastest-growing high-technology companies, that have taken even more aggressive stands on this issue).

71. A brief checklist of this literature includes, Russell L. ACKoff, THE DEMOCRATIC CORPORATION: A RADICAL PRESCRIPTION FOR RECREATING CORPORATE AMERICA AND Rediscovering Success (1994); Farid Elashmawi \& PhILJP R. HaRris, MUlticultural MaNAGEMENT: NeW SKILlS FOR Global SUCCESS (1993); MiCHAEL

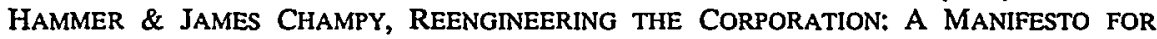
BUSINESS REVOLUTION (1993); MARILYN LODEN \& JUDY B. ROSENER, WORKFORCE AMERICA!: MANAGING EMPLOYEe DIVERSITY AS A VITAL RESOURCE (1991); MANAGING THE MUlTicultural WORKFORCE: STRATEGIES FOR HUMAN ResOURCE PROFESSIONALS (Rosalind M. Schwartz ed., 1992); Gifford PinCHOT \& ElizABETH Pinchot, THE END OF BuREaucracy and THE Rise OF THE INTElligent ORganization 4, dustjacket (1993) (contending that "[b]ureaucracy is no more appropriate to sophisticated work today than serfdom was to the factory work of the early Industrial Revolution" and 
Diversity Advantage: How American Business Can Out-Perform Japanese and European Companies in the Global Market Place, argues that "U.S. success in the new global marketplace rests in the rich cultural, ethnic, and racial mix of its population, which will make it better able to adapt to foreign markets and global customer bases." 72

The crucial first step in developing [high-performance work] teams is teaching increasingly diverse groups of employees to understand and value different races, ethnic groups, cultures, languages, genders, ages, religions, sexual orientations, levels of physical abilities, and family structures. Only by assisting employees to respect differences will the corporations be able to build trust ... and to develop in the employees the skills and tools to deal effectively with diverse customer bases, diverse stockholders and diverse influences in a highly competitive marketplace. ${ }^{73}$

The Nike corporation is obviously very successful in communicating both with impoverished Indonesian laborers ${ }^{74}$ and with impoverished inner-city young Black men. ${ }^{75}$ Yet whether these exercises in multiculturalism are making the world a better, more unified place or are exercises in efficient colonization are not answerable within multiculturalism's analytic framework. Similarly, the Phillip Morris tobacco company has long been a pioneer for this sort of racial justice, so much so that in the 1950s the White supremacist monthly White Sentinel attempted to organize a boycott against the company because "Phillip Morris, Inc. has the worst race-mixing record of any large company in the nation[;] ... [it was] the first in the tobacco industry to hire negroes instead of

that "[o]nly freedom and community will work"); R. ROOSEVELT THOMAS, JR., BEYOND RACE \& GENDER: UNLEASHING THE POWER OF YOUR TOTAL WORK FORCE BY MANAGING DIVERSITY (1991).

72. John P. Fernandez, The Diversity AdVANTAGE: How AMERICAN Business

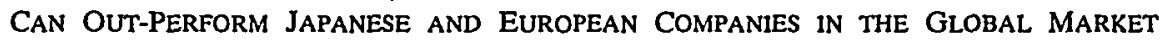
PLACE 2 (1993).

73. Id. at 1 .

74. See Press Release from Nike Inc., NIKE and Sourcing: A Primer (on file with author) (arguing that the company's Indonesian operations provide a "model" of how corporations "can help a rural workforce make the transition to light manufacturing").

75. Nike's successful marketing campaigns employing sports superstars like Michael Jordan are well known. See J. Linn Allen, Nike, Air Jordan High-Flying Act, CHI. TRIB,, Oct. 7, 1993, at 1; Jim King, Bullish Investors Want to Be Like Nike, ATLANTA CONST., June 16,1993, at B2. Recently the company has begun reaching out to feminists with an ad series in upscale fashion magazines and to postmodernists in general in TV spots featuring William Burroughs and Dennis Hopper. 
Whites for executive and sales positions ... [and] the first cigarette company to advertise in the negro press." recently gave over $\$ 2.4$ million to 180 Black, Latino, and women's groups. ${ }^{77}$ Perhaps the fact that the product of this company kills more Black people im a year than crack cocaine in a decade should cause us to question the value of this sort of commitment to racial justice. ${ }^{78}$

I believe it is no accident that the very institutions in which multiculturalism has had the most effect in restructuring institutional practices-research universities and transnational corporations-are those institutions most dedicated to the facilitation and exploitation of an efficient globalized market system-a system that incidentally undermines the economic, cultural, and social foundations of non-elite communities. I am not suggesting that proponents of multiculturalism are the dupes of transnational capital, or that multiculturalism can have only one meaning (i.e., the legitimation of neocolonialism). I am also not arguing for a kind of vulgar economic determinism in which ideologies flow inexorably from an abstracted "needs of capital" or the "mode of production." Rather, I am arguing that systems of belief, culture, systems of meritocratic evaluation, and systems of organizing production all fit together in a dynamic and complementary way in particular historical moments. Today, business operations are increasingly

76. RICHARD J. BARNET \& JOHN CAVANAGH, Global DREAMS: IMPERIAL CORPORATIONS AND THE NEW WORLD ORDER 197 (1994) (quoting Myron Levin, The Tobacco Industry's Strange Bedfellows, Bus. \& SOC'Y REV., Spring 1988, at 16).

77. Id.

78. Illicit drug businesses similarly are affirmative action employers. Although the toli of the crack epidemic is undoubtedly high and not fully calculated-because crack-related homicide is included in the general homicide rate, crack-related deaths are categorized either under specific bodily maladies or "adverse effects," and the effects of crack's welldocumented relationship to infant morbidity and child abuse are not so easily tabulated-the leading killers in the United States remain, in order, heart disease, malignant neoplasms (cancer), accidents and adverse effects, cerebrovascular diseases, strokes, and chronic obstructive pulmonary diseases, many of which can be smoking-related. BUREAU OF THE CENSUS, supra note 30, at 96 (Table 128).

Blacks are known to have the highest rates of tobacco use and smoking-related illness in the United States, and the five-year survival rate for lung, mouth, and throat cancer has typically been lower for Blacks than for Whites. BUREAU OF THE CENSUS, supra note 30, at 143 (Table 212); see Bob Herbert, Tobacco Dollars, N.Y. TrMES, Nov. 28, 1993, at D11. There is some speculation that Black smokers are less successful in detoxifying certain carcinogenic chemicals found in cigarettes, but whether the cause for this is poverty-related or some other reason is unclear. Marilyn Chase, Health: Smoking Study Sparks Debate on Race, WALL ST. J., Apr. 15, 1994, at B1. 
decentralized, and capital markets are computer networks in which decisions made half a world away are executed in nanoseconds. The communications and information technologies of command and control developed for the military have made it possible for global corporations to operate all over the world without a single center. Decisional centers are no longer necessary or efficient. In foreign policy, "free trade" has replaced the "White man's burden" as the enlightened way to deal with those economies from which we lope to gain advantage. And in the liumanities, multiculturalism and "appreciating difference" liave replaced western civilization as the universal aestlıetic. Multiculturalism may not exist simply to serve the needs of capital, but it nevertheless reflects the perspective and serves the interests of the emerging global elite. Combined witl an economically ignorant politics of representation, multiculturalism allows major corporations and their supporting institutions to buy inexpensively the perception that they are fair and socially responsible. And because multiculturalism takes the leat off transnational corporations by implying that a liberatory politics need not attack their power, it is harming the very communities it seeks to help. ${ }^{79}$

The racially sensitive, multicultural corporation is going to be the death of non-White communities. For example, General Electric (GE) lias long been at the forefront as an "enlightened" corporation, witl an established, aggressive affirmative action program and multicultural marketing. ${ }^{80}$ Yet GE was listed in a Wall Street

79. Cf. WiLson, supra note 9, at 179-82.

80. See Theodore V. Purcell \& Daniel P. Mulvey, The Negro in the ElecTRICAL MANUFACTURING INDUSTRY (University of Pennsylvania Racial Policies of American Industry Series No. 27, 1971). In the post-World War II period, GE was "the first nationwide company to include the [newly accredited] Howard engineering school in its regular college recruiting." Id. at 37. In the same period, GE president Charles Wilson chaired the President's Committee on Civil Rights. Id. In the early 1950s, some White workers at a Louisville plant who protested the employment of Black workers by striking were fired. Id. at 41 . GE's Dr. Louis Rader helped integrate the Virginia school system as well as his own Waynesboro plant. Id. In the early 1960s, GE voluntarily established an equal opportunity employment division of its employee relations office and, in an effort to stir Black interest in electrical engineering training, created a booklet describing 50 of its Black employees at all levels, which the company then distributed to 60,000 career and guidance counselors in the United States. Id. at 49-50, 55. The fact remains, though, that in 1969 "only 2.3 [percent] of the white collar workers in the industry were Black in contrast to the blue collar situation where 10.5 percent were Negro." Id. at 52 . In the "Big Four"-GE, Western Electric, Westinghouse, and RCA-the oyerall 1969 figures were slightly higher: $3.3 \%$ of white collar workers and $12 \%$ of blue collar workers were Black. Id. at 84 . 
Journal study of companies in which African-Americans suffered disproportionate job losses in 1990-1991. A GE spokesperson explained that the racially disproportionate firings were the result of the company's entirely economically rational decision to close its Columbia, Maryland plant, 39\% Black, and its Cicero, Illinois plant, $80 \%$ Black, and move production to more cost-efficient facilities with lower wages in Alabama, Georgia, and Mexico. ${ }^{81}$

Do not assume that these companies necessarily are disingenuous: ${ }^{82}$ the same Wall Street Journal study that revealed that Blacks suffered a highly disproportionate net employment loss in the last recession also showed that African-Americans gained disproportionately in managerial, professional, and technical jobs. ${ }^{83}$ The problem, of course, is that there are and will continue to be far fewer of those sorts of jobs that were gained than the kind of blue-collar jobs that were lost. Most people are never going to be Yuppies, no matter how much our educational system improves. Note that some $70 \%$ of the U.S. workforce is still employed in jobs classified as unskilled or semiskilled. ${ }^{84}$ Popular culture and the dominant myths of the article-writing class notwith-

81. See Ric Manning, GE Expected to Ask Lonisville Workers to Help Trim Costs, LOUISVILLE COURIER-J., Jan. 10, 1993, at 1A; Rochelle Sharpe, Losing Ground: In Latest Recession, Only Blacks Suffered Net Employment Loss, WALL ST. J., Sept. 14, 1993, at A13. This labor market analysis does not even touch on the issue of environmental racism, a problem structurally embedded in the framework of global capitalism. See Anthony Taibi, Environmental Justice, Structural Economic Theory, and Community Economic Empowerment, 9 ST. JOHN'S J. LEGAI. COMMENT. 491 (1994) (arguing that the fight against environmental racism must be based on community economic empowerment).

82. There is, however, some evidence that the racial effects of corporate relocations and restructurings are not simply the unintended outcomes of changes rooted elsewhere. Sociologist Gregory D. Squires persuasively argues that

$[w]$ hen corporations seek out greener pastures they tend to seek out whiter ones as well, in part because of the presumption of a relatively greater attrac-

tion to unions on the part of blacks, in part to avoid equal opportunity requirements by avoiding areas where minorities are not in the picture, and in part

due to the perpetuation of traditional stereotypes and old-fashioned prejudice. SQUIRES, supra note 49, at 3 (citations omitted); see also Joleen Kirschenman \& Kathryn M. Neckerman, "We'd Love to Hire Them, But ... ": The Meaning of Race for Employ. ers, in The Urban Underclass 203 (Christopher Jencks \& Paul E. Peterson eds, 1991); Robert E. Cole \& Donald R. Deskins, Jr., Racial Factors in Site Location and Employment Patterns of Japanese Auto Firms in America, CALIF. MGMT. Rev., Fall 1988, at 18, 21; Reginald Stuart, Business Said to Have Barred New Plants in Largely Black Communities, N.Y. TIMES, Feb. 15, 1983, at A14.

83. Sharpe, supra note 81.

84. JeFF FAUX \& THEA LEE, THE EFFECT OF GEORGE BUSH'S NAFTA ON AMERICAN WORKERS: LADDER UP OR LADDER DOWN? 18 (1992). 
standing, most folks are and will continue to be lower-middle-class. The optimistic vision of America as the land of (or potentially the land of) desirable jobs is false. It is a myth that keeps policymakers from improving the quality of working poor and lowermiddle-class life by holding out the hope that everyone can instead aspire to be an upper-middle-class professional. They cannot. Although the rate of increase may be impressive for isolated desirable jobs such as computer scientists or systems analysts, examination of employment data by increase in total number of jobs reveals that the job categories that will have the largest increases in actual numbers (rather than rate of change) include clerks, cashiers, truck drivers, retail salespeople, child caretakers, and nurse's aides and home care attendants for the elderly and disabled. ${ }^{85}$ The great service economy "boom" in such areas as finance, insurance, and real estate-touted by policymakers in the early 1980s as the areas that would create the post-industrial job expansion-is now proving to be offering largely low-paid and increasingly insecure employment. ${ }^{86}$ Worker training and education alone will not solve this problem: indeed many very poor countries already produce an overabundance of gifted and highly educated and skilled people for whom no adequate employment exists. ${ }^{87}$ Moreover, the destruction of local markets means fewer entrepreneurial smallbusiness opportunities as well. ${ }^{88}$

85. U.S. BuREAU OF THE Census, supra note 30 , at 410-11 (Table 638, Civilian Employment in Occupations with the Largest Job Growth: 1992 to 2005, and Table 639, Civilian Employment in the Fastest Growing and Fastest Declining Occupations: 1992 to 2005).

86. See Richard J. Barnet, Lords of the Global Economy, NATION, Dec. 19, 1994, at 754, 755 ("[I]n 1992, the 4.9 million non-supervisory employees in these industries were making an average hourly wage of [only] \$10.14.").

87. See Richard J. Barnet, The End of Jobs, HARPER's, Sept. 1993, at 47, 48-50. This also means that some of America's most skilled workers are beginning to face the same punishing competition and wage pressures from abroad as previously felt only by blue-collar workers. Although globalization is creating new high-tech jobs, we cannot assume that they are reserved for Americans. See G. Pascal Zachary, High-Tech Firms Shift Some Skilled Work to Asian Countries: Like Blue-Collar Employees, West's Professionals Face Job Competition Abroad, WALl ST. J., Sept. 30, 1994, at A1.

88. See Paul Gruchew, Unchaining America: Communities Are Finding Ways to Keep Independent Entrepreneurs in Business, UTNE READER, Jan.-Feb. 1995, at 17. For example, a significant amount of data has been amassed demonstrating that Wal-Mart, the nation's largest retailer, destroys smaller, locally owned and controlled businesses in the areas in which it locates. See Kenneth E. Stone, Impact of Wal-Mart Stores on Other Businesses in lowa, 1983-1993 (1994) (available from the Department of Economics, Iowa State University); Kenneth E. Stone, Competing with the Mass Merchandisers, SMALL 


\section{TOWARD A POSITIVE VISION OF THE LOCAL: THEORETICAL CONSIDERATIONS}

Globalization's costs may far exceed its returns. The global economy is not a democratic institution. Universalist theories of progress have naturalized globalization in part by pathologizing the local as backward and prejudiced, the enemy of progress. It is time to start reevaluating what we mean by progress. We need to focus our concern for people's feelings into real respect for actual places, and protect our neighbors' desire for self-determination as we would our own. We cannot assume that multinational corporations care about the well-being of our particular communities or that the next environmental "sacrifice zone" will not be in our backyard. The organization for such a political realignment has already started taking place, but people have to do the work themselves; we simply cannot wait for the government to come up with some watered-down reform and then complain because it will not work..$^{89}$

BUS. FORUM, Spring 1991, at 33, 35-38; The Impact of Discount Superstores on Small Business and Local Communities: Hearings Before the House Comm. on Small Business, 103d Cong., 2d Sess. (1994) (testimony of Thomas Muller, economist and writer). In response to Wal-Mart's encroachments, many independent merchants have organized resistance. See Sari Kalin, Wal-Mart Supporters, Opponents Face Off, PATRIOT LEDGER, June 21, 1994, at A1 (describing fight by small downtown businesses of Quincy, Massachusetts to keep Wal-Mart out of their town); Ellen Neuborne, David Beats Goliath in Wal-Mart Pricing War, USA TODAY, Oct. 13, 1993, at B1 ("Advocates of the old-fashioned Main Street business district have long complained that Wal-Mart sweeps into small towns, underprices everyone and drives longtime local businesses under."); Fran Silverman, State's Communities Put up a Wall of Resistance to Wal-Mart, HARTFORD COURANT, Nov. 28, 1994, at A3.

89. See Jeremy Brecher \& Tim Costello, global Village or Global PilLAGE: ECONOMIC RECONSTRUCTION FROM THE BOTTOM UP 4-8 (1994); see also Taibi, supra note 42 , at $1517-20$. William Greider explains,

[T] globalization process produces three interlocking economic consequences that together are deleterious to everyone's well-being. First, it destroys capital on a large scale by rendering productive investments useless to the marketplace. That is the meaning of closing viable factories that can no longer meet the price competition.

... Second, the overcapacity permanently depresses wage levels worldwide, since no workers anywhere can organize and bargain very successfully against the threat of a closed factory, whether they are well-paid Americans or impoverished peasants working somewhere in the Third World.

Finally, these two effects ... combine to guarantee that global demand can never catch up with global supply. . . . Too many factories making too many goods for a marketplace where too many families lack the wherewithal to buy them.

William Greider, Who Will Tell the PeOPLE 400 (1992). An increasingly global labor market depresses the wages of American workers. To the extent that capital is 
It is frequently claimed that the efficiency gains of globalization, the full use of "comparative advantage," and the channeling of capital to investments with the highest rate of return will make the world a more wealthy place. It is unclear whether this is so, but it is very clear that the bulk of any increased wealth will inure to a small elite, while workers and their communities will bear much of the cost. The most important effect of globalization may be that it greatly strengthens the bargaining power of transnational corporations in their negotiations with workers and governments and local businesses. In addition, global investors and business elites have no interest other than economic in the places where their capital is invested, and therefore, they acknowledge no responsibility for communities, neighborhoods, equity, or social and public investment. $^{90}$

The three inajor competing theoretical systems of political econoiny of this century-laissez-faire, Marxism, and Keynesianism-are all universalist ideologies that deny the centrality of place and the importance of preserving local power, including power over local markets, to human liberation. ${ }^{91}$ In all three systems,

mobile, global corporations, all other things being equal, search for locations that promise the lowest wages and the least regulation of workplace safety and environmental pollution. See Noam Chomsky, Notes on NAFTA: "The Masters of Mankind", NATION, Mar. 29, 1993, at 412, 414 (describing the NAFTA as an opportunity for corporations to "reap enormous profits" at the expense of workers and the environment); Jim Hightower, NAFTA-We Don't Hafta!, UTNE READER, July-Aug. 1993, at 97 (noting the NAFTA "officially encourages" the loss of companies and "whole industries"); Marc Levinson et al., Can Anyone Spare a Job?, NEWSWEeK, June 14, 1993, at 46, 47 (identifying movement by many companies to "ship less skilled parts of the job" to low-wage countries); G. Pascal Zachary \& Bob Ortega, Age of Angst: Workplace Revolution Boosts Productivity at Cost of Job Security, WALL ST. J., Mar. 10, 1993, at A1. Although this practice may raise wages in some places, it is a disaster for the American worker. Even assuming greater productivity per worker, American wages have a long way to fall before they are in equilibrium with the wages of workers in Malaysia or Mexico. Taibi, supra note 42, at 1518; see also Barnet, supra note 87 , at 48-49 (discussing the shrinking opportunities to work for decent pay throughout the world).

90. See Wallace Katz, Letting Go of Liberalism, TiKKUN, Sept.-Oct. 1992, at 73.

91. Stuart Hall explains,

The great discourses of modernity-in this respect Marxism no less than liberalism, both in their different ways, Enlightenment "grand narratives"--led us to expect, not the revival but the gradual disappearance of the nationalist passion. Attachments to nation, like those to tribe, region, place, religion, were thought to be archaic particularisms which capitalist modernity would, gradually or violently, dissolve or supersede. Socialism, the "counter-culture of modernity" ... was equally predicated on the subsumption of these particularisms into a more cosmopolitan or internationalist consciousness.

Hall, supra note 3, at 353. 
community, culture, religion, and family are just matters of taste or irrationality that will dissolve as superior systems of meaning crowd them out. In all three, ethnic identity is a problem, not a foundation for humane existence. The racial and economic Left has heretofore allied itself with the institutions of universalism and "progress" against the institutions of local authority and tradition. In the past, for people of color, local authority was the major locus of economic, social, political, and cultural oppression. And, to be sure, old-fashioned racism continues to blight the lives of Black people, and the $\mathrm{Ku}$ Klux Klan still operates. ${ }^{92}$ However, the economic base on which their institutional power traditionally rested is gone. Local bankers, landowners, shopkeepers, manufacturers, and professionals are becoming marginal operators or functionaries of larger concerns or are going bankrupt. Local market elites are redundant in a global market economy. ${ }^{93}$

But the enemy of your enemy is not necessarily your friend. The "downsizing" of corporations, the export of blue-collar jobs, the "reinventing" of government, the erosion of small-business niches, the flattening of corporate hierarchies with the elimination of middle-management jobs, and the consolidation and deregulation of the financial industry-all part of the dynamic of the globalization of economic activity-are eroding the economic foundations of non-elite communities, while the universalization of consumption patterns erodes their cultural foundations as well. The elite of the emerging global, multicultural marketplace is colonizing

92. Klanwatch, a publication of the Southern Poverty Law Center, continues to track the activities of the Ku Klux Klan.

93. The changing structure of our economy is eroding the job security and business opportunities that many took for granted, and the children of small-city professionals and well-to-do civic leaders are particularly hard hit by these changes. The opportunities and lifestyle that the children of such local elites assumed was their birthright no longer exist. Job insecurity is no respecter of class. Middle managers and other white-collar victims caught in the fallout of a transforming U.S. economy and "downsizing" corporate structure account for an increasing proportion of the newly unemployed. JAMES L. MEDOFF, The NeW Unemployment 9 (1992) (Harvard Institute of Economic Research Discussion Paper No. 1620) (prepared for the use of Sen. Lloyd Bentsen) (on file with author). Success for small businesses is increasingly elusive, and many that do manage to survive do so at the cost of their autonomy and independence. The days when young doctors and lawyers could just go into business for themselves are practically over; professionals increasingly find that they must do long hours of drone work for impersonal organizations in order to pay back their loans. Craftsmanship and technical expertise also no longer are guarantors of job security or autonomy. See George J. Church, We're \#1 and It Hurts, TIME, Oct. 24, 1994, at 50. 
all of our communities with a thoroughness and efficiency that nineteenth-century imperialists could never have dreamed of, and we are made complacent with the thought that it is happening because of unchangeable natural forces that are like the tide, rather than because of political and institutional machinations. ${ }^{94} \mathrm{I}$ believe that answering the question, "Which side are you on?"- the side of global capital or the side of local authority-is in part a question of whether you prefer equality of opportunity in a structure with little opportunity, or unequal opportunity, but more of it.

Black Nationalism and some strands of Critical Race Theory offer valuable perspectives on this dilemma. Black Nationalists have argued that Black people should eschew participation in institutions outside of their communities, both because they doubt that Black people will ever truly "enjoy full acceptance in American society" and because even if integration were achievable, it would, in the words of Robert Browne, constitute "a sort of painless genocide." ${ }^{, 95}$ As Browne wrote in 1968,

[T] he black masses ... have watched with alarm as the more fortunate among their ranks have gradually risen to the top only to be promptly integrated off into the white community-absorbed into another culture.... [I]ntegration actually increases the white community's control over the black one by destroying institutions, and by absorbing black leadership and coinciding its interests with those of the white community. ${ }^{96}$

Browne's analysis of American race relations as analogous to colonial relations is not too extreme, particularly given the effects of the most integrated, multicultural corporations on the Black community. ${ }^{97}$ To the extent that corporations and government bureau-

94. See SQUIRES, supra note 49, at 3; see also BENNETT HARRISON \& BARRY BLUESTONE, THE GREAT U-TURN: CORPORATE RESTRUCTURING AND THE POLARIZING OF AMERICA 3 (1988) (arguing that the economic downturn is a result of business and government policies); Edward S. Herman, The Natural Rate of Unemployment, Z MAG., Nov. 1994, at 62 (suggesting that invocations of the figure of "nature" serve an important ideological function for conservative social policy). For the classical critique of the invocation of nature in economic thought to serve right-wing ideological ends, see THORSTEIN VEBLEN, ECONOMICS AND EVOLUTION (1898).

95. ROBERT S. BROWNE \& BAYARD RUSTIN, SEPARATISM OR INTEgRATION: WhICH WAY FOR AMERICA? 10-11 (1968).

96. Id.

97. This analysis is complicated by the fact that defining what-if anything specific-is comprehended by the concept of "the Black community" is highly controversial and uncertain. See Kal Alston, The Pragmatics and Politics of Difference, MIDWEST MODERN 
cracies successfully penetrate the market for consumption items and services in local communities, and at the same time undermine the ability of local businesses and institutions to service their local markets, colonization in roughly the classical sense of the term is an appropriate way to describe that relationship. ${ }^{98}$

Any postmodernist, of course, would be quick to point out that the binary White and Black identities on which Nationalist theories are based are neither coherent, stable, nor enduring. ${ }^{99}$ Socially, economically, and culturally, we are simply too interdependent to make substantial political separation viable or even

LANGUAGE JOURNAL, Spring 1993, at 58, 59.

98. This economic analysis is reinforced by the fact that many of these communities were originally deprived of their self-sufficiency by force, and that today their acquiescence to governmental authority is maintained by force, by armed agents of the state. The police's position in many Black neighborhoods resembles that of a foreign army of occupation, inspiring fear, but not respect, among the people "served." See STOKELYY CARMICHAEL, STOKELY SPEAKS 86-87 (1971). Carmichael, a former chairperson of the Student Non-Violent Coordinating Committee, is now known as Kwame Toure.

The description of the systematic aspect of American racism as a form of colonialism has a rich literature in Black Nationalist thought. The term "colonization" was apparently first used in a comprehensive analysis of the situation of African-Americans by Harold Cruse. Harold Cruse, An Afro-American's Cultural Views, in REBELlion OR Revolution? 48-67 (Harold Cruse ed., 1968); see also Harold Cruse, Negro Nationalism's New Wave, NEw LEADER, Mar. 19, 1962, at 16; Harold Cruse, Revolutionary Nationalism and the Afro-American, in 2 STUdIES ON THE LEFT 12-13 (1962). By the mid-1960s, the neocolonial analogy was widely used by Black Nationalists. See, e.g., ROBERT L. ALLEN, BLACK AWAKENING IN CAPITALIST AMERICA: AN ANALYTIC HISTORY 5-17 (1969); JAMES E. BLACKWELI, THE BLACK COMMUNITY: DIVERSITY AND UNITY 12-14 (1985); StOKely CARMichael \& Charles V. Hamilton, BlaCK POWER: THE POltTics OF LIBERATION IN AMERICA 2-56 (1967); ELDRIDGE CIEAVER, POST-PRISON WRITINGS AND SPEECHES 57-72 (Robert Scheer ed., 1969); HUEY NEWTON, ESSAYS FROM THE MINISTER of DEFENSE HuEY NEWTON 2-10 (1968); ALPHONSO PINCKNEY, RED, BLACK AND GREEN: BLACK NATIONALISM IN THE UNITED STATES 8-13 (1976); ROBERT STAPLES, INTRODUCTION TO BLACK SOCIOLOGY 13-14 (1976); see also, Abd-l Hakimu Ibn Alkalimat, The Ideology of Black Social Science, in THE DEATH OF WHITE SOCIOLOGY 183-88 (Joyce A. Ladner ed., 1973).

Comprehending the relations between Blacks and Whites on a colonial model, Black Nationalists argue that even Black control of the Black community would be insufficient if it meant merely that Black people would administer the same structural power relations that previously existed between White and Black communities. Black Nationalists thus argue that the mere pluralist racial diversification of existing American institutions and social patterns is simply another form of the colonial relationship and that a radical transformation of the institutional practices of the status quo would be necessary before identifiable Black and White communities could relate on a just basis. See Peller, supra note 4 , at 810 .

99. Nor, given current demographic trends, do they comprehend America's emerging racial makeup. See Deborah A. Ramirez, Multicultural Empowerment: It's Not Just Black and White Anymore, 47 STAN. L. REV. (forthcoming May 1995). 
desirable. But the impulse toward community self-determination and integrity is one to be fostered, not suppressed. Gary Peller, Anthony Cook, and others have linked postmodern social theories to a localist, group-specific politics, arguing that we must recognize the cultural situatedness of all social and institutional relations, and explicitly negotiate over the terms of our integrated social spaces. ${ }^{100}$ Peller argues that individual identity exists in the historical context of particular traditions and communities, and thus existing communities should not be understood as "a distortion that must be transcended or [as] the result of domination that must be erased." 101 In opposition to the liberal image that group identity and status are opposed to the possibility of individual freedom, Peller sees in community status a basis on which we can struggle for freedom. ${ }^{102}$ Cook argues that we can create a "critical multiculturalism," which would use both group historical identity and the universal spiritual connection of all people to forge its politics. ${ }^{103}$ A politics of community empowerment, unlike separatist Nationalism, would require its participants to work both for the empowerment and betterment of their own communities, and for the establishment of a mutually beneficial larger framework of economic and political interaction.

I believe that we can create a transracial political movement for community empowerment. Throughout American history an ideology of local autonomy, home rule, and the enduring meaning of systems of tradition, group, family, and place has always existed alongside and often in opposition to the ideology of universal individualist liberalism. ${ }^{104}$ Although the localist impulse has rarely been given the coherent intellectual framework of its competitors, it remains a most powerful resource for political action. In living rooms, union halls, and churches across America, working people are already organizing their communities in "grassroots"105

100. Anthony E. Cook, The Spiritual Movement Towards Justice, 1992 U. ILL. L. REV. 1007, 1017-18; Peller, supra note 4, at 794-95.

101. Peller, supra note 4, at 794 (referring specifically to African-American identity).

102. Id.

103. Professor Cook has used this phrase in discussions with colleagues, but has not yet used it in print. The point is generally expressed in Cook, supra note 100, at 1018.

104. See generally CHRISTOPHER LASCH, THE TRUE AND ONLY HEAVEN: PROGRESS AND ITS CRITICS (1991) (providing a positive history of antiliberal communitarian politics in America); see also Michael KAzIN, ThE POPULIST PERSUASION: AN AMERICAN HisTORY (1994) (defining populism and discussing its continuing use as a form of political rhetoric).

105. The Reverend Johnny Ray Youngblood, East Brooklyn Congregations pastor and 
groups around such issues as hazardous waste dumping, community investment, and affordable housing. Unlike cosmopolitan liberals, members of such groups consider the associations of church, family, and neighborhood to be viable sites around which progressive struggle may be organized. Many of these local organizations are hinked by a national organization, the Industrial Areas Foundation (IAF), originally formed in Chicago in the 1930s by Saul Alinsky. IAF organizer, priest, philosopher, and sometime-professor Leo Penta explains that the radical tool for IAF organizing, the "relational meeting", "is the embodiment of a practice that is the antithesis of the liberal paradigm's view of an unencumbered self with its attendant atomistic individualism."106 IAF organizers "begin[] by establishing relations with the enduring community institutions that people rely on-churches and synagogues and civic associations."107 The IAF "espouses a political doctrine that is rooted in the language of the Gospels." 108 And notably, although start-up funds come from the sponsoring parishes and churches, "the members must immediately develop their own capacity to be self-sustaining and financially independent." 109 Within the "IAF network of community organizations" there are more than 2 million dues-paying families nationwide-more than the number of Democratic and Republican party contributors combined. ${ }^{110}$

Liberals and conservatives, lacking any viable blueprint for dealing effectively with our social and economic problems, look increasingly to community-based organizations for ideas, but unfortunately, too often this results in government programs that adopt the form but reject the substance of community empowerment-not surprisingly, since both Democrats and Republicans depend on their connections with and the money of global corporations and their upper-middle-class managers. Politicians now

\footnotetext{
subject of a recent book about the Black church, stated in an address, "[W]e are not a 'grass-roots' organization. Grass roots grow in smooth soil! Grass roots are shallow roots! . . O Our roots are deep roots!" J1M SLEEPER, THE ClOSEST OF STRANGERS: LIBERALISM AND THE POLITICS OF RACE IN NEW YORK 155 (1990) (quoting Youngblood). For a biography of Reverend Youngblood, see SAMUEL G. FREEDMAN, UPON THIS RoCK: THE MiRACles OF a BlaCK CHURCH (1993).

106. Leo J. Penta, Citizen Politics, Relational Organizing, and the Practice of Democracy 10 (Sept. 15, 1993) (unpublished manuscript, on file with author).

107. GREIDER, supra note 89 , at 224-25.

108. Id.

109. Id.

110. Id. at 248.
} 
glibly quote the old saying, "Give a man a fish and you feed him for one day; teach a man to fish and you feed him for life," but community organizers know that what really matters is who owns the pond, both because skills and tools alone are not enough to ensure long-term community prosperity, and because man does not live by bread alone. ${ }^{111}$

Yet despite the many local successes that grassroots activist community groups have achieved, the community organizing movement has not developed much of a national political presence, nor has it developed a coherent body of doctrine or theory. Most academic discussions of promoting "community" and "civil society" are addressed to the spiritual and relational crises and existential angst of the mobile professional class, not to the economic crisis and considered anxiety of downwardly mobile lower-middle-class people and the changing material circumstances that are undermining their communities and institutions. Although "communitarian" intellectuals have made important contributions to current political discourse by critiquing how the national obsession with individualism and libertarian rights has eroded the bonds of community, degraded our culture, destabilized our moral compasses, and victimized our children ${ }^{112}$ they have neglected discussion of how these ills are more completely analyzed within a structural economic framework. ${ }^{113}$ A broad-based communitarianism must address such issues as the undermining of the economic security of middleclass families caused by the rising power of global corporations, the declining real wage of American workers, the rise of contingent and part-time no-benefits, no-job-security employment, the ability of multinational corporations to play communities off against one another, the globalization of capital markets, and other such structural economic shifts. Stable families, and communities and community institutions rest on a foundation of economic sta-

111. Matthew 4:4 (quoting Deuteronomy 8:3).

112. See, e.g., ROBERT N. BELLAH ET AL., HABITS OF THE HEART: INDIVIDUALISM AND COMMITMENT IN AMERICAN LIFE 143-52 (1985); AMITAI ETZIONI, THE SPIRIT OF COMMUNITY: RIGHTS, RESPONSIBILITIES, AND THE COMMUNITARIAN AGENDA 24-30 (1993); MARY ANN GLENDON, RIGHTS TALK: THE IMPOVERISHMENT OF POLITICAL DisCOURSE 171-83 (1991).

113. For an excellent discussion of the inadequacy of the "communitarian" agenda, see Charles Derber, Coming Glued: Communitarianism to the Rescue, TIKkun, July-Aug. 1993, at 27; see also Amitai Etzioni, On Communitarianism and Its Inclusive Agenda, TIKKUN, Sept.-Oct. 1993, at 49 (Etzioni's response to Derber); Charles Derber, Charles Derber Responds, TIKKUN, Sept.-Oct. 1993, at 51 (Derber's rejoinder). 
bility, a foundation that is increasingly eroding in America. To the extent that the ideology of individual entitlement is an independent force eroding community, we must analyze how that ideology largely arose to serve elite big-business interests for career-obsessed workers and conspicuous consumers.

Modern industrial society and a globally organized economy foster geographic mobility, thereby lessening individuals' attachment to and concern for particular places. Not surprisingly, then, the less mobile lower middle class has very different notions of the meaning of "community" than do we of the mobile, article-reading and -writing class. In the lower-middle-class worldview, community is something one is born into, not a "choice," and its content is rooted in geographically specific local experiences. Such traditional definitions of "community" bear little resemblance to the notions of community that emerge from highly mobile upper-middle-class cosmopolitan experience. Postmodern identity politics and such concepts as the "community of internet users" are unfathomable in the lower-middle-class worldview, which understands such positions as interest or affinity groups, and sees the demands of their members for community status as an unconscionable claim that would, if granted, usurp their own community status. ${ }^{114}$ In contrast, we of the upper middle class are constantly on the move and thus we cannot help but treat places and their parochial cultures disrespectfully; every place is economic raw material for ideas and images, development, extraction, or markets. ${ }^{115}$ One of the outstanding contributions of environmentalism more generally to public discourse is its reintroduction of both a moral and a material challenge to our practice of subordinating the rest of our social imperatives to economic growth (and a narrowly defined economic growth at that). Our way of life, in production and consumption, is both socially disastrous and environmentally unsustainable. The environmentalism of the upper middle class, however, is rooted in a very abstract notion of sustainable development: its brand of "environmental awareness" propagates the view that our environmen-

114. Cf. John P. Bariow, Is There a There in Cyberspace?, UTNE READER, Mar.-Apr. 1995, at 52, 52 (part of a series of articles called "Cyberhood vs. Neighborhood").

115. As Tim Luke has observed, "Building a community in a particular location, accepting it on its own ecological terms, working to adapt a sustainable way of life, cherishing it for its unique differences are foreign notions" to our mainstream common sense. Tim Luke, Community and Ecology, in ThE GRaywolf AnNual Ten: Changing ComMUNITY 207, 214-15 (Scult Walker ed., 1993). 
tal problems are simply the product of aggregated bad individual choices based on lack of awareness (rather than as being inherent in our system of production) and thus is ultimately counterproductive to environmental well-being-even if it does result in significantly increased recycling efforts. ${ }^{116}$ In contrast, for the immobile poor and lower middle class, grassroots activism on environmentalism and sustainable community economic development are issues of survival. The creation of real opportunity and the avoidance of environmental catastrophe require us to reincorporate place into our concept of community and reconnect the economies of our communities to their supporting ecoregions. ${ }^{117}$

In advocating community empowerment and local, environmentally sustainable economic development, I am not simply being a Luddite or indulging in nostalgia for a mythic past that never was and cannot be. I am a product of New York City, and I have no desire to "go back to nature" or live in a parochial ethnic enclave. What I am arguing, however, is that our stock image, our collective common sense, of the process of modernity and of progress as natural, unilinear, and irreversible is false. The evolution of society is the product of political choices made in particular historical circumstances. We can choose to alter the structural imperatives that erode community life.

The belief we Americans hold in never-ending economic growth is becoming increasingly indefensible. The promise it holds out of a widespread high standard of living and economic security has not been and cannot be kept. Although possessed of a few more toys than their ancestors, most people in the world do not enjoy a particularly high standard of living, ${ }^{118}$ and, moreover, the

116. According to many environmentalists, household recycling is an upper-middle-class guilt-reducing placebo that diverts attention from more serious and complex environmental issues whose amelioration would challenge the socioeconomic order. Some evidence even suggests that curbside recycling increases more serious air pollution problems because of the increased truck traffic that such efforts entail. The major beneficiary of these efforts has been the waste management industry, whose profits have skyrocketed in recent years. Jeff Bailey, Waste of a Sort: Curbside Recycling Comforts the Soul, but Benefits Are Scant, WALL ST. J., Jan. 19, 1995, at A1.

117. Luke, stupra note 115 , at 215 .

118. Although hunger and poor sanitation provide a fairly objective yardstick for determining what constitutes a low standard of living, determining what constitutes a high standard of living is largely an ideological question of value. The number of families in the United States who own such items as microwave ovens (84\% in 1990) and VCRs (69\% in 1990) is indeed impressive, but Gross National Product statistics also include in measures of our well-being such articles of commerce as children in day-care and parents 
conditions necessary for security ${ }^{119}$ and a meaningful, moral life are increasingly undermined. With more local control over politics

in nursing homes, headache remedies, security services, cancer therapy, hazardous waste clean-up, drug rehabilitation, psychological counseling, and other expenditures that we might reasonably prefer to count as representing a low standard of living. The United States also ranks very poorly in terms of leisure and family time. Jonathan Peterson, Life in U.S., as Graded on the Curve, L.A. TIMES, Apr. 11, 1993, at A1, A16. Almost onethird of America's 68.5 million families make less than $\$ 25,000$ per year, with almost one in ten making do on less than $\$ 10,000$. Carol J. Castaneda and Margaret $\mathrm{L}$. Usdansky, Tax-Cut Fever Washes over Washington, USA TODAY, Dec. 14, 1994, at 1A (figures corrected Dec. 21, 1994). Whatever may be the value of and possibilities for continued conventionally understood growth in the developed world, it strains credulity to imagine that it can much benefit the overwhelming majority of the world's people. The United Nations Development Program estimates that the disparity between the richest countries in the world (bearing in mind that at least half of our people are not so rich) and the poorest in terms of income and access to basic resources (safe drinking water, sufficient caloric intake, medical attention and sanitation, education, and so on) is about 150 to 1 . United Nations Development Program, human Development Report 34 (1992). The North, with about one-fourth of the world's population, consumes $70 \%$ of the world's energy, $75 \%$ of its metals, $85 \%$ of its wood, and $60 \%$ of its food. Id. at 35 .

119. For example, the economic insecurity of the American workforce is greatly increasing. See G. Pascal Zachary, Censis Bureau Confirms Eroding Wages: Low Pay, Fewer Benefits Shadow Employment Gains, WALL Sr. J., Jan. 25, 1995, at A2 (noting that in addition to the significantly lower pay of the newly created jobs compared to those that have been lost, a high percentage of new jobs do not provide health benefits).

In Europe, Japan and Canada, as in the United States, many of the jobs being shed today will never return. ... [M]anagement dogma everywhere is to keep costs to a minimum by figuring out where the organization adds value and eliminating everything-reports, products, managers, entire departments-that doesn't.

... Only the most vital operations must remain under the corporate roof; everything else is handled by networks of joint ventures, spinoffs, subcontractors, temporary workers. ... The result is higher productivity. But for most workers it means more instability and insecurity.

Levinson et al., supra note 89, at 47. A Wall Street Journal series on the new unemployment entitled "Down the Up Escalator" explained in the first installment,

Millions of American workers are embarking on a journey of insecurity, and professional and highly skilled employees are not exempt. All are affected by the unprecedented confluence of four trends.

...

... Many labor specialists fear that the four horsemen of the workplace-global competition, technology, downsizing and the growth of the contingent workforce-will cause wages to continue to fall, creating a nation increasingly divided into haves and have nots.

Zachary \& Ortega, supra note 89, at A1. Middle managers and other white-collar workers account for an increasing proportion of the newly unemployed. MEDOFF, supra note 93. Worse, these laid-off executives and white-collar workers may never again be able to command high salaries. Bruce Nnssbaum et al., Downward Mobility: Corporate Castoffs Are Struggling Just to Stay in the Middle-Class, Bus. WK., Mar. 23, 1992, at 56, 58. This problem is worldwide. See Barnet, supra note 87, at 47; Jeremy Brecher, Global Unemployment at 700 Million, Z MAGAZINE, Nov. 1993, at 45, 47-48. 
and markets, many communities might do better. Mainstream thinking calls for communities and individuals to "think globally and act locally" to shore up our weakening power in the emerging global system. A transracial, environmentally conscious politics of community empowerment needs communities and individuals who instead can "think locally and act globally."120

\section{STRATEGIC PROPOSALS FOR COMMUNITY EMPOWERMENT}

We have assumed the inevitability of globalization and failed to recognize its potential for harm for so long that other possibilities for the evolution of society may seem impossible. Nevertheless, there is much we can do to begin the struggle, and there are many fronts on which to fight. In national and international law and politics there are strategies available for facilitating local power and for negotiating between local economies and global entities. At home, there is work to be done in promoting the well-being of small business and the creation of opportunities-often there are even useful laws already in place that are simply not being enforced. On the cultural front, we can exercise some control by forcing producers of information to negotiate, not dictate, in the creation of collective common sense. Finally, one of the potentially fruitful side effects of the national government's diminishing moral authority is that more and more attention is being focused on local politics, issues, and accountability. Government cannot do our work for us or save us from ourselves, but it can be a tool that facilitates more just social relations.

We must develop alternatives to the existing practices and institutions of community, property, consumption, and production that are both rooted in local experiences and linked into a larger global strategy. The strategy must develop on two levels: a level of local autonomy, cultural integrity, and community economic development, and a national and global level for establishing the framework for local success. The ideas that follow are presented as tenuous indicators of potentially fruitful avenues of exploration, designed as much to provoke discussion and suggest areas for further research as to advocate a particular political trajectory.

First, a movement primarily interested in empowering local cominunities must nevertheless be concerned with national and

120. Luke, supra note 115 , at 216 . 
global policy. The predicament is that many national or local policy initiatives aimed at increasing local control could have negative consequences for a locality's position in the global economy. As Jeremy Brecher and Tim Costello have observed,

Globalization has largely outflanked the efforts of local and national governments, political parties, trade unions and grass-roots organizations to protect popular interests. Corporations force workers, communities and countries to compete to attract investment, bringing about a worldwide downward leveling: Each tries to reduce labor, environmental and social costs below the others, leading to a disastrous "race to the bottom" in which the conditions of all tend to fall toward those of the poorest and most desperate. ${ }^{121}$

Transforming the economies of our local communities requires that we transform the national and transnational economies. ${ }^{122}$ The struggle for community empowerment must include creating international coalitions to reverse the race to the bottom by raising international standards to resist the global corporate agenda. The vehicles to achieve this could include international environmental and labor rights campaigns, social charters in international trade agreements, the establishment of corporate codes of conduct, and the use of boycotts and the voting power of pension and public funds. ${ }^{123}$

Second, on the domestic front, we must work to create more widespread opportunities for small producers, the ownership of capital, and the acquisition of skills. For example, employee ownership offers great possibilities for community economic development, and policies to promote it have the potential to achieve popularity across the political spectrum. ${ }^{124}$ Already, workers

121. Jeremy Brecher \& Tim Costello, Taking on the Multinationals, NATION, Dec. 19, 1994 , at $757,758$.

122. Brecher, supra note 119 , at 48 .

123. Id. Evidence that the community empowerment movement is moving toward global action based on local thinking can be found in the participation of many grassroots environmental justice groups in anti-North American Free Trade Agreement (NAFTA) protests. Understanding that the NAFTA will strengthen the bargaining power of pollution-producing transnational corporations, many grassroots environmental justice organizations forged broad cross-border coalitions to oppose the NAFTA. Although unsuccessful, the broadening of horizons occasioned in that struggle may provide the groundwork for future collective action. See Rick Held, Crossing the Line: Corporations Are Exporting Environmental Racism to Mexico, Dumping Dangerous Jobs and Toxic Waste on Communities of Color, 21 S. Exposure, Winter 1993, at 20, 21.

124. SQUIRES, supra note 49, at 22-34. Employee stock ownership plans (ESOP), for 
share in some degree of ownership in more than 11,000 firms employing over 12 million workers (almost $12 \%$ of the workforce). Although no panacea-employees are often given an ownership stake only after a company is in deep trouble, and in most cases the employee share is small and its power over management limited-there is some evidence that such firms give workers more training opportunities and greater responsibility, are less likely to lay off workers in downturns, provide more avenues for upward mobility, and exhibit less racial disparity, than do other firms. ${ }^{125}$ More broadly, such goals, far from being unrealizable and Utopian, could be promoted in small, incremental steps using resources already available. An important place for lawyers and legal intellectuals to start would be to salvage antitrust law from the socalled consumer welfare ideologies of Robert Bork ${ }^{126}$ and the Chicago School, ${ }^{127}$ which in practice serve the interests of big business, and make antitrust law instead serve the interests of local

example, enjoy broad support. A series on ESOPs in the Wall Street Journal has noted that particularly with smaller businesses, ESOPs seem to benefit both the company and the employees. Timothy L. O'Brien, Small Businesses Keep Workers by Selling Them a Stake, WALL ST. J., Feb. 12, 1993, at B2. Their recent history features some dramatic successes, notably Brooklyn's Advanced Technological Solutions and the City Pride Bakery in Pittsburgh. See William S. Kowinski, The Tale of City Pride: People Who Wouldn't Give Up, SmITHSOnian, Oct. 1993, at 118; Thomas J. Lueck, Save the Business, Keep It in Brooklyn, N.Y. Times, July 17, 1994, at C4; Dawnyielle L. Peeples, Workers Use a Buyout to Buy In, BLACK ENTERPRISE, Jan. 1994, at 19.

125. SQUIRES, supra note 49 , at 23.

126. See Robert Bork, The Antrtrust Paradox 51, 164, xi (1978) (new introduction 1993):

The only legitimate goal of American antitrust law is the maximization of consumer welfare. ... . [T] he law should never attack [concentrated market] structures, since they embody the proper balance of forces for consumer welfare .... The judge must not weigh against consumer welfare any other goal, such as the supposed social benefits of preserving small businesses against superior efficiency

127. Judge Richard A. Posner, a leading light of the Chicago School, posits the following apologia for the existence of concentrated markets in arguing against antitrust enforcement:

If the leading firms in ... [concentrated] industries are able, by virtue of concentration, to obtain supracompetitive profits, these profits should act as a magnet to other firms in the economy and their entry will deconcentrate the industry. . . Persistent concentration implies either that the market in question simply does not have room for many firms (economies of scale) or that some firms are able persistently to obtain abnormal profits by cost reductions or product improvements that competitors and new entrants are unable to duplicate. Neither case is an attractive one for public intervention designed to change the market structure.

Richard A. Posner, The Chicago School of Antitrust Analysis, 127 U. PA. L. REv. 925, 945 (1979). 
businesses. ${ }^{128}$ From banking ${ }^{129}$ and trade regulation to land use and local government law, ${ }^{130}$ there is much work for legal practitioners and thinkers in promoting environmentally sustainable, ${ }^{131}$ racially just, community empowerment and local-market economic development.

The third policy direction I have in mind, is contesting the idea that the good life consists of leisure and obsessive consumerism. The stories and images with which we tell ourselves who we are and what we want to be play an integral role in determining what we are willing to he with and what we will fight for. We need to redefine our culture so that the values of work and responsibility to community are reincorporated into our ideas about human fulfillment and progress. Although many politicians are now calling for such efforts, they are blind to the fact that their

128. The influence of the Chicago School has restricted all discussions of antitrust to the rhetoric of competition and efficiency. See Rudolph J. Peritz, A Counter-History of Antitrust Law, 1990 DUKE L.J. 263, 264. But antitrust law embodies other values by "produc[ing] and ratif[ying] not only competitive but also distributive and socio-political effects." Id. at 320. This was recognized in Brown Shoe Co. v. United States, 370 U.S. 294 (1962) (discussing the Celler-Kefauver amendment to $\S 7$ of the Clayton Act), in which Chief Justice Warren wrote, "[W]e cannot fail to recognize Congress' desire to promote competition through the protection of viable, small, locally owned businesses. Congress appreciated that occasional higher costs and prices might result from the maintenance of fragmented industries and markets. It resolved these competing considerations in favor of decentralization." Id. at 344. Senator Kefauver demanded in the floor debates to the amendment, "Shall we permit the economy of the country to gravitate into the hands of a few corporations ... ? Or . . . are we going to preserve small business, local operations, and free enterprise?" 96 CONG. REC. 16,450 (1950). Justice Brandeis was a strong supporter of antitrust as a vehicle of what he called "industrial democracy." Louis D. Brandeis, The Curse of Bigness: Miscellaneous Papers 39 (Osmond $\mathrm{K}$. Fraenkel ed., 1934) (noting that "industrial liberty" is deemed by every citizen as "far more important" than political liberty and stating, "Can this contradiction-our grand political liberty and this industrial slavery-long coexist? Either political liberty will be extinguished or industrial liberty must be restored."); see also WALTER ADAMS \& JAMES W. Brock, ANTITRust Economics on Trial: A Dialogue on the New laissezFAIRE 125 (1991) ("[A] decentralized power structure is at the very root of America's political democracy and the American brand of free enterprise economics."). Adams and Brock expound on this notion in THE BIGNESS COMPLEX 87-103 (1986).

129. See Taibi, supra note 42 .

130. See generally Gerald E. Frug, The City as a Legal Concept, 93 HARV. L. Rev. 1057 (1980) (critiquing the relative powerlessness of governmental entities intermediate between the state and the individual, and arguing that the empowerment of such entities would enhance democratic values and economic opportunity through decentralization).

131. Local ownership and control would help counteract unsustainable production and consumption because "not only the benefits of consumption, but also the costs of production would then be immediately evident at the local level rather than only in distant environmental 'sacrifice zones.' " Luke, supra note 115, at 217. 
unwillingness to challenge the power of big business is at odds with such a commitment. We must take control of television and the information superhighway away from the promoters of individualist consumption and irresponsibility, as conservative Christians are attempting to do in their own way. ${ }^{132}$ We ought to join conservatives in condemning the degradation of culture into entertainment, but we must hammer home the point that this problem is more the product of laissez-faire economics and corporate media money-making than it is of liberal permissiveness. No liberal social engineer came up with MTV and tabloid "news" shows. Capitalists did.

Finally, if increased local responsibility is to be successful, we must work to diminish the power of paternalistic central government bureaucracies, as well as transnational corporations. The conservative critique of the social engineering bureaucratic state-although sometimes just a cover for mere selfishness, corruption, subservience to private interests, and sexism and racism-is not entirely off the mark. The Left has acted as the apologist for government long enough; "The left's reply [to this conservative critique] most often seems to be little more than the rather lame assertion that government must do those things the market does poorly, combined with a defense of existing government programs-even when these are scandalous failures."133 The success of the Right has in part been that it has better articulated the concept that the realm between the individual and the state is most important to human fulfillment; we must point out how the Right's neoclassical economic program has done as much to undermine community and civil society as the "nanny" state of the social engineering Left ever did.

Clearly, the dismantling of the social engineering state contains some troubling possibilities. ${ }^{134}$ We must carefully distinguish our brand of community empowerment from that represented in

132. In this regard, conservative Christians have developed what has been characterized as a "quasi-Marxist discourse on alienation" that has successfully galvanized their populist movement; unfortunately, with few notable exceptions, Christian populists, like Republican and Democratic "communitarians," do not make a sustained challenge to the economically powerful. See Marc Cooper, God and Man in Colorado Springs, NatioN, Jan. 2, 1995, at 9, 11 .

133. Jeremy Brecher, Affairs of State, NATION, Mar. 6, 1995, at 319 (reviewing HILARY WAINWRIGHT, ARGUMENTS FOR A NEW LEFT: ANSWERING THE FREE-MARKET RIGHT (1994)).

134. Luke, supra note 115 , at 218. 
the congressional Republicans' "Contract With America,"135 which seeks to free local governments from the demands of unfunded federal mandates, but will neither ensure the availability of local resources nor prevent the "race to the bottom" as local communities compete for jobs and tax revenues. ${ }^{136}$ Indeed, at this moment of globalization, the Right's formulation of standardless decentralization serves not to empower, but to speed the "race to the bottom" for less powerful local communities. Leo Penta is troubled by the use of the term "empowerment," explaining that it has been used "as a cover for neglect and nearly unrestricted privatization, as well as a racially laden code for individualistic solutions to communal and systemic issues." ${ }^{137}$ As Penta argues, "the promise of local, communal power without economic amelioration and institutional change" is empty. ${ }^{138}$ Decentralization and community empowerment must be linked to global standards that set a floor on marketplace competition in order for such efforts actually to empower local communities.

We must seek to understand the complex relationship between the local and larger centers of power, both governmental and market. In economic matters, we must resist blindly accepting the notion that the globalization of markets is inevitable and for the best; rather, we must work to discover what mix of local, regional, and global markets best meets our needs and aspirations. In governmental matters, we need to work toward figuring out how to foster local autonomy in ways that maximize the probability of local success, under a system of standards that prevents the race to the bottom. ${ }^{139}$ In creating a new federalism we also need to be

135. Republican Nat'l Committee, Contract with America (1994) (on file with Republican Nat'l Committee).

136. See Bill Lambrecht, Unfunded Mandates: Expensive, Unpopular, ST. LouIS PoSTDISPATCH, Jan. 29, 1995, at 1A, 10A (discussing the proposed ban on unfunded mandates included in item 8 of the "Contract with America"); GOP House Members Offer Agenda for National Renewal in Contract with America, MINNEAPOLIS STAR TRIB., Oct. 30, 1994, at A20 (reprinting the so-called Job Creation and Wage Enhancement Act); see also H.R. 5, 104th Cong., 1st Sess. (1995); S. REP. No. 1, 104th Cong., 1st Sess. (1995) (unfunded mandates); Jeanne Ponessa, Democrats Draw in the Reins on Mandates Legislation, Cong. Q. WKLY. REP., Jan. 14, 1995, at 149; Craig T. Ferris, Jlst Another Unfunded Mandate?, BOND BUYER, Jan. 23, 1995, at 10. For a thorough analysis of the Republican initiative, see OMB Watch, Eye of the Newt: An Analysis of the Job Creation and Wage Enhancement Act (OMB Watch, Nov. 29, 1994).

137. Penta, supra note 106 , at 4.

138. Id.

139. As Robert Kuttner explains, 
mindful of the danger of reviving "traditional" modes of racism. ${ }^{140}$

At this time in which progressive politics is characterized by sectarianism, incompatible group agendas, and mutual suspicion, the movement for community empowerment presents a fertile site for progressive intellectuals and activists of all varieties to join with each other and with ordinary people (who identify with a variety of political persuasions) to work in a genuinely common struggle. Of late, the Left has seemed to join with the "public choice" theory Right in the notion that there is no common public interest, but only the aggregation of individual and imterest-group interests; a politics of community empowerment offers the possibility of turning this around. As Jeremy Brecher has argued,

The left has been maneuvered into being the defender of government; to escape from this box it must remake itself as the advocate of social action in civil society. The left can reclaim the idea of empowerment from the right-but only if it redefines government as a vehicle for supporting popular initiatives rather than a substitute for them..$^{141}$

The challenge for the Left is to obtain legitimacy through grassroots social action and work to create common-sense awareness of the fact that there is no such thing as "the market" separate and apart from its legal and regulatory framework; at the same time, the Left must labor to create a new framework, one that will serve the needs of ordinary people of all races and cultures better than current arrangements, but do so without perpetual bureaucratic intervention. We must restructure "the market" so that it will

The global intelligentsia may think of itself as stateless, and global capital may see nation-states as anachronistic encumbrances. But the state remains the locus of the polity, notwithstanding the best successes of supranational institution building. And the polity remains the structure best suited for counterbalancing the excesses of the market. Therefore it does matter if American workers have access to high-productivity jobs, and it matters whether enterpriscs that provide those jobs are located in the United States. . . . This article may strike some purists as distastefully mercantilistic, but until the millenium of global government comes or until all nations have roughly the same labor and social standards, it is a necessary accommodation to the reality of political economy. ... One pursues such policies not because one dislikes foreigners but because the invisible hand does not produce equitable outcomes and the visible hand remains a national one.

ROBERT KưTTNER, THE END OF LAISSEZ-FAIRE 24 (1991).

140. See Luke, supra note 115 , at $216-19$ (describing ways in which local power can resist racism and xenophobia).

141. Brecher, supra note 133 , at 322 . 
operate in ways that will bring about both procedural equality and substantive justice. Success in the struggle for racial justice requires that our strategies not be of the sort that can be dismissed as presenting mere questions of special-interest charity and redistribution by bureaucracy; rather, racial justice will be achieved when it is commonly understood as a spontaneous product of a social system that operates for the common good.

\section{POSTSCRIPT}

I think that many intellectuals reject the possibility of local power as a positive good because most of our images of the striving for ethnic identity and community power are deeply negative: fascism, lynch mobs, and the tragedy of the former Yugoslavia. But as grassroots groups show us, there is another way. I argue that so many expressions of localist power have been negative precisely because those leaders and thinkers who would give it a humanistic, cooperative expression have abandoned the attempt to do so and instead followed a universalistic course, ceding tradition, family, and community to the political Right. In the face of an intense human need for particularistic systems of meaning and power, tied to a specific place, we should not be surprised that largely conservative ideologies fill the void. That so many xenophobic and nationalistic demagogues have achieved power in the world does not mean that we should ignore or suppress those who are attracted to them, but rather that we need to figure out ways to harness their desires in positive directions.

I am assuming here that at the end of a structurally transformative social struggle we will end up with pretty much the same kind of human beings we started out with. I am not claiming some sort of hard-and-fast essentialized human nature, but I am suggesting that there are some constants in human motivation that must be accounted for in any political vision. A political program whose success depends on the creation of a new kind of person is doomed to failure. Our emphasis must be less on how we can transcend strife, competition, and struggle, and more on how we can change the structures of social interaction to promote the constructive and limit the destructive outcomes of those sorts of interactions. $^{142}$ We can and must change the rules of the game, the

142. A similar point was made by James Madison in defense of the Constitution. See 
rewards attendant on winning and losing, and even the nature of the game itself, but we cannot much change the players. Our reliance on the success of attempts to do so has and will doom the transformative enterprise to failure. We will not create the new socialist man. The Age of Aquarius is never coming. "[I]f all men are brothers, then the ruling model is Cain and Abel."143 Moreover, the vision of the good as this harmonious state in which we all hold hands and sing "Kumbaya, My Lord" around the campfire is insipid. As has often been said, the perfect is the enemy of the good. No, the dynamic and realistic vision for transformative social struggle is not universal brotherhood, but detente. Respect for difference does not mean assuming that your "enlightened" point of view will win out, or creating a cosmopolitan society in which difference does not make a difference; ${ }^{144}$ rather, respect for difference means respect for the worthy opponent and working for a functional truce, not harmony.

The FEDERALIST No. 10 (James Madison).

143. Arthur A. Leff, Unspeakable Ethics, Unnatural Law, 1979 DUKE L.J. 1229, 1249.

144. See Hall, supra note 3, at 362 (arguing for a notion of "hybridity" different from "the old internationalist grand narrative, from the superficiality of old style pluralism where no boundaries are crossed, and from the trendy nomadic voyaging of the postmodern or simplistic versions of global homogenization-one damn thing after another or the difference that doesn't make a difference"). 